Bartłomiej Krzysztan, Ph.D. is an assistant professor at the Institute of Political Studies of Polish Academy of Sciences. Graduate of Political Sciences at Université Libre de Bruxelles and Political Science and Cultural Studies at the University of Wrocław. His research interests include political anthropology, political and cultural memory, post-colonialism, ethnic and national identities, especially in the South Caucasus region.

Bartłomiej Krzysztan

Institute of Political Studies of Polish Academy of Sciences

ORCID: 0000-0001-5632-6884

bkrzysztan@isppan.waw.pl 


\title{
HISTORICAL ANALOGY AND POLITICAL CONTINUITY AS TECHNOLOGIES OF POWER. THE ARMENIAN GENOCIDE AND NAGORNO-KARABAKH CONFLICT INTERRELATION IN THE CONTEMPORARY ARMENIAN POLITICS
}

\author{
Bartłomiej Krzysztan \\ Institute of Political Studies of Polish Academy of Sciences, Poland
}

\begin{abstract}
Analyses of the transformation and political change in Armenia pays noticeable attention to the dominant role of discourses of the Armenian Genocide and the conflict over Nagorno-Karabakh for nation and state-building processes. At the same time, the two issues usually are investigated separately. Attempts are rarely made to interpret the interrelation and connection between the two narratives. Nevertheless, the trauma-based discourse of memory is linking the two narratives as technology of power through discursive structures/mechanisms of analogy and continuity. Methods of discourse analysis combined with expert interviews, internet questionnaires and ethnographic field research aim to analyse the crucial discursive patterns and mechanisms. Hypothetically, instrumentalized and ideological usage of combined narratives are impacting the political changes, in Post-Soviet Armenia. The article touches upon only one aspect of the discursive interrelation between the Armenian Genocide and the Nagorno-Karabakh issue. Thus, the subject under the question is the impact of the usage of historical analogy and the idea of continuity understand as technologies on contemporary Armenian politics of memory.
\end{abstract}

Keywords: Nagorno-Karabakh conflict, Armenian Genocide, politics of memory, technologies of power, historical analogies, continuity.

The article was submitted on 07.07.2021 and accepted for publication on 08.11.2021.

How to Cite: Bartłomiej Krzysztan, "Historical Analogy and Political Continuity as Technologies of Power. The Armenian Genocide and Nagorno-Karabakh Conflict Interrelation in the Contemporary Armenian Politics," International Journal of Armenian Genocide Studies 6, no. 2 (2021): 7-39. 


\section{Introduction}

This paper is a part of the broader project which core aim is to conduct in-depth research investigating the interrelation between the politics of memory about the Armenian Genocide and Nagorno-Karabakh conflict with the notions of transformation and political change in Armenia between 1988 and 2018. The aim of the study is also to reflect on and describe the experiences of the political revolution(s), ruptures and breakthroughs and subsequent possible changes in attitudes towards ideologized discourses. This interrelation and dependence operate on many different levels of discourse, so it is impossible to exhaust the topic completely in one paper. Given this, this article has two objectives. First, it contains extended reflections on potential epistemological, methodological, and theoretical approaches to the issue. Secondly, the case study presents the results of preliminary research of the exploratory case study focusing on the question of historical analogy and ideological continuity understood as technologies of power. These will be used in the further development of research on the specific issue itself that is the focus of the article. The case study of Armenia could be used as a theoretical and methodological matrix for analysis of analogical processes of discourse instrumentalization, interrelated with transformation and change in post-Soviet conflict spaces.

Recognition of the events of 1915 as genocide plays an extremely important role as one of the bases of the international policy of the Republic of Armenia after 1991. The impact of this issue on domestic politics is also significant, as exemplified by the lack of diplomatic relations with the Republic of Turkey, mainly determined by the negationist policy pursued by Ankara. The consequence of the lack of diplomatic relations is, in turn, the blockade of the country, which has a significant impact on its economic situation. Quite a few studies have been written about the political conditions related to politics, including the politics of memory towards the recognition of the Armenian Genocide. ${ }^{1}$ Two of the rare examples of the analytical approach to the question of politics of genocide were proposed by Thomas de Waal and Vartan Matiossian. ${ }^{2}$

Equally important is the Nagorno-Karabakh issue, which, through successive armed clashes and escalations, has an undeniable influence on the process and dynamics of change, including, above all, successive breakthroughs/ruptures within the Armenian political system. The deep militarisation of the country and strategic decisions (such as the alliance with Russia) have a significant impact on the internal situation. Up to date, quite meticulous research and analysis has been carried out on this issue as well. ${ }^{3}$ However, attempts

\footnotetext{
1 Maria Koinova, "Diaspora Coalition-Building for Genocide Recognition: Armenians, Assyrians and Kurds," Ethnic and Racial Studies 42, no. 11 (2019): 1-21; Ronald Grigor Suny, "They Can Live in the Desert but Nowhere Else": A History of the Armenian Genocide (Princeton: Princeton University Press, 2017); Taner Akçam, A Shameful Act: The Armenian Genocide and the Question of Turkish Responsibility (New York, NY: Picador, 2007); Cathie Carmichael, Genocide before the Holocaust (New Haven: Yale University, 2009); Donald E. Miller and Lorna Touryan Miller, Survivors: An Oral History of the Armenian Genocide (Berkeley: University of California Press, 1999).

2 Thomas de Waal, "The G-Word: The Armenian Massacre and the Politics of Genocide," Foreign Affairs 94, no. 1 (2015): 136-48; Vartan Matiossian, The Politics of Naming the Armenian Genocide. Language, History and 'Medz Yeghern' (New York: Bloomsbury Publishing, 2021).

3 Levon Chorbajian, The Making of Nagorno-Karabagh - From Secession to Republic (New York: Palgrave
} 
to combine both issues/narratives within a single discursive space have so far received limited discussion. ${ }^{4}$ The objectives, the paradigm and the state of art allowed the following research questions to be posed: how the historical analogies and idea of continuity is instrumentalized as technology of power in the contemporary Armenian politics? Although in research that draws at least in part on the achievements of political anthropology to make any hypotheses seems to be a methodological abuse, for the sake of clarity of rhetoric, one working quasi-hypotheses can be made: being the subject to ideologization, the issue of the interrelation between the Armenian Genocide and the Nagorno-Karabakh conflict used as a technology of power in contemporary Armenian politics, is its significant variable. Those question and hypothesis are complementary for the main question of the broader project: how the instrumentalized discursive interrelation between narratives of memory of the Armenian Genocide and the Nagorno-Karabakh conflict impact the political change in Armenia between 1991 and 2020?

\section{Methodologies, materials, and methods}

The article is a stand-alone case study. As mentioned above in the objectives section, the premise is to present two levels of research on the discursive relationship between the Armenian Genocide and the Nagorno-Karabakh conflict. Thus, in the first dimension, the article undertakes theoretical and methodological reflections on ways to study the interrelation of these issues. This is because the question of how to study a particular phenomenon is important in the context of in-depth research. In the second dimension, the article presents the results of preliminary research conducted in Armenia in April and May 2021. The research was designed as an exploratory case study. Its primary purpose as an introduction to further in-depth research was to gather information along multiple dimensions. The primary aim of this research was to seek answers to the question of what discourse elements (narratives) are necessary to explore in the context of research problem. Ultimately, this preliminary research was supposed to refine both the research questions and hypotheses. The next issue was to consider how to research the different narratives. The second methodological approach was a broad discourse analysis. ${ }^{5}$ Both approaches are treated as methodologies

\footnotetext{
Macmillan, 2001); Laurence Broers, “From Frozen Conflict' to Enduring Rivalry: Reassessing the Nagorny Karabakh Conflict," Nationalities Papers 43, no. 4 (2015): 556-576; Ohannes Geukjian, Ethnicity, Nationalism and Conflict in the South Caucasus: Nagorno-Karabakh and the Legacy of Soviet Nationalities Policy (New York: Routledge, 2016); Claude Mutafian, "The Karabagh in Twentieth Century," in Caucasian Knot: The History and Geopolitics of Nagorno-Karabagh, ed. Levon Chorbajian, Patrick Donabedian, and Claude Mutafian (London: Zed Books, 1994).2001

4 Geukjian, Ethnicity, Nationalism and Conflict; Vicken Cheterian, "The Uses and Abuses of History: Genocide and the Making of the Karabakh Conflict," Europe-Asia Studies 70, no. 6 (2018): 884-903; Victor A. Shnirelman, The Value of the Past: Myths, Identity and Politics in Transcaucasia, Senri Ethnological Studies 57 (Osaka: National Museum of Ethnology, 2001); Harutyun Marutyan, Iconography of Armenian Identity: The Memory of Genocide and the Karabagh Movement (Yerevan: Gitut'yun Publishing House, 2009); Henry E. Hale, Patronal Politics: Eurasian Regime Dynamics In Comparative Perspective (Cambridge: Cambridge University Press, 2014).

5 Ruth Wodak and Michael Meyer, Methods of Critical Discourse Studies (New York: SAGE Publications Ltd, 2015); The Routledge Handbook of Critical Discourse Studies, eds. John Flowerdew and John E. Richardson (New York: Routledge, 2017); Marianne W. Jorgensen and Louise Phillips, Discourse Analysis as Theory and Method, (London, Thousand Oaks, California: SAGE Publications Ltd, 2002).
} 
rather than methods, to set out a certain paradigmatic approach to the materials and data collected through the methods used in the fieldwork. This multidimensional approach that juxtaposes seemingly strongly divergent issues, allows for an in-depth cognitive look. Discourse analysis, in turn, seems to be the best way to analyse such disparate narrative representations as public memory spaces, expert narratives and results of survey questionnaires.

To find appropriate research methods, various qualitative methods were used in the preliminary research. First, the method of expert interviews was used. ${ }^{6}$ As a supplement, a survey questionnaire with the same questions was distributed among the Armenian university students. The questionnaire was used to conduct 11 in-depth expert interviews in a semi-structured format (same question, open-ended response option with no restrictions plus an open-ended comment option at the end). ${ }^{7}$ The same questions were used in the online questionnaire presented to the students however, the option to answer was reduced to closed answers (eight possibilities - definitely yes, yes, rather yes, rather not, no, definitely not, difficult to say, don't know). For question 2, the possible answers were as follows: definitely significant, significant, rather significant, not significant, definitely not significant, hard to say, don't know. For question 8, the possible answers were as follows: definitely increased, increased, rather increased, rather decreased, decreased, decreased significantly, difficult to say, don't know. This survey yielded 36 responses. ${ }^{8}$ The questionnaire contained 9 questions, additionally, 5 sociological questions were asked at the beginning of every interview (gender, age, education, field of study, place of origin). In the case of expert interviews and questionnaire research, it is important to make one essential annotation. The research was conducted in April/May 2021, less than six months after the end of the Second Karabakh War, on the eve of the early parliamentary elections held in June 2021. The political tension, the trauma of the experience of defeat in the war, resulting in the loss of control over a significant area of the Nagorno-Karabakh Republic, certainly had a significant impact on the emotions, and therefore on the perception of the situation, and therefore also on the issue of the basic subject of the study.

Secondly, classical ethnographic fieldwork with usage of participant observation and visual anthropology was conducted. ${ }^{9}$ During the research, the most significant public representations of memory were visited and documented. As such, both state and private museums, sites of memory and carefully selected public representations are understood. The

\footnotetext{
6 Alexander Bogner, Beate Littig, and Wolfgang Menz, "Introduction: Expert Interviews - An Introduction to a New Methodological Debate," in Interviewing Experts, ed. Alexander Bogner, Beate Littig, and Wolfgang Menz, Research Methods Series (London: Palgrave Macmillan UK, 2009), 1-13; Stefanie Döringer, “"The Problem-Centred Expert Interview'. Combining Qualitative Interviewing Approaches for Investigating Implicit Expert Knowledge," International Journal of Social Research Methodology 24, no. 3 (2020): 1-14.

7 Interviews in digitized and transcribed form in the author's archive.

8 The questionnaire is available as an annex.

9 D. Soyini Madison, Critical Ethnography: Method, Ethics, and Performance (Thousand Oaks, California: SAGE Publications, Inc, 2011); Sarah Pink, Doing Visual Ethnography (London, Thousand Oaks, California: SAGE Publications Ltd, 2006); Marcus Banks, "Doing Things with Photographs and Films," in Visual Methods in Social Research (London: Sage, 2001); Marcus Banks, "Visual Anthropology is not Just Ethnographic Film: The Visual as Material Culture," in Visual Research Methods, ed. Peter Hamilton (London: Sage, 2006); Michael Angrosino, Obserwacja w Nowym Kontekście. Etnografia, Pedagogika i Rozwój Problematyki Społecznej, trans. Filip Rogalski, vol. 2 (Warszawa: Wydawnictwo Naukowe PWN, 2010).
} 
initial exploratory case study research presented in the article is the basis for undertaking in-depth explanatory research.

\section{Results}

\section{Expert interviews and Survey Questionnaires}

The questionnaire entitled "On the relation between the Armenian Genocide and the Nagorno-Karabakh conflict" was used in both the expert interviews and the online questionnaires completed by students. The questions were composed according to a cognitive key relating to the different dimensions of the existence, shaping, and changing relations of narratives about the Armenian Genocide and the Nagorno-Karabakh conflict.

The first question was composed as follows: In your opinion, is there a connection between the Nagorno-Karabakh conflict and the Armenian Genocide issue? This is a question central to the whole discussion of the interrelation under investigation. It is an ontological question about the individual's belief whether the relation between two phenomena really is. In the questionnaire, $38.9 \%$ of the interviewees indicated that such a relationship definitely exists, $41.7 \%$ answered that it exists, $11.1 \%$ that it rather exists. The remaining $8.3 \%$ indicated to answer "it is difficult to say". The absence of a negative answer may be an indication of how potentially formed the social perception of the existence of the relationship is. In the interviews conducted with experts, the answers are varied, and the issue of interrelation is dealt in a more nuanced way compared to questionnaires. Experts emphasise that to reliably describe the relationship between the two phenomena, it is necessary to separate the perspectives on it in different accounts of socio-political reality. The first criterion can be referred to as the perception criterion. It is based on the dichotomy between social perception and professional (scientific and political) perception. According to all interviewees, there is certainly a belief in the relationship between the two phenomena in public perception. It is mainly due to the deep "immersion" in the history of Armenian society and the presence of history in political discourse as its essential component. It was repeatedly underlined in the interviews that, especially during the Second Karabakh War Armenian politicians (mainly Prime Minister Nikol Pashinian), repeatedly stressed the issue of the "existential threat to Armenians", analogous to the experience of the Armenian Genocide of 1915. At the same time, "genocidal intentions" on the part of both Turkey and Azerbaijan were emphasised. Meanwhile, at the level of professional perception, there was a clear tendency to emphasise the relationship between the two phenomena, which is realised in the creation of specific academic and political multi-level narratives. The second criterion of division can be referred to as the criterion of substantive content. It is based on three dimensions in which the interrelation between the Armenian Genocide and the Nagorno-Karabakh conflict should be considered.

The first dimension of the relationship is the question of ideological continuity. It was repeatedly stated in the interviews that in both public and professional perception, there is a belief that there is an ideological continuation of intentional actions against Armenians. This continuity would be rooted in basing policies towards Armenia, Nagorno-Karabakh, 
recognition, and remembrance of the Armenian Genocide, both in Turkey and Azerbaijan, on Pan-Turkic ideas. An example of ideological continuity cited more than once was Enver Pasha's role in the decision-making triumvirate of the Committee of Union and Progress. His responsibility in the narrative came down to the implementation of Pan-Turkic ideas, above all the concept of uniting nations of Turkic origin in Anatolia, the Caucasus, and Central Asia. Armenians were to be an obstacle to the realisation of this goal, and a decision was taken to annihilate them, which was first carried out in the Ottoman Empire and then continued in the Caucasus, above all in Nagorno-Karabakh, Nakhijevan and Baku. There, the continuation of the annihilation process was to be handled in 1918 by Nuri Pasha, Enver's younger brother and Commander-in-Chief of the Army of Islam. ${ }^{10}$

The second dimension of the interrelation is the question of historical analogy and the continuity of intentional actions. In this context, Soviet policy towards the Kemalist Turkish Republic, which was normalised in the 1920s, was emphasised at the expense of the Armenians. At the same time, the Turkish influence on the internal Soviet decisions of the early 1920s, which resulted in the creation of the Nagorno-Karabakh Autonomous Oblast within the Azerbaijani Soviet Socialist Republic, and the annexation of Nakhichevan to Azerbaijan, was clearly emphasised. The decisions taken with the agreement of 10 November 2020, ending the Second Karabakh War, are considered historically analogous to the Turkish-Soviet agreements. ${ }^{11}$

The third dimension of the relationship is the issue of political instrumentalization, both within internal politics in Armenia and in the assessment of Turkish and Azerbaijani policies. In this context, it is worth pointing out that serious doubts have also been raised about linking the two phenomena. They are supposed to stem primarily from an assessment of the systematic and organised policy of repression against Armenians, which is completely different in the case of the Ottoman genocidal policy and Azerbaijan's policy towards Nagorno-Karabakh. At the same time, an important aspect that unites all three dimensions in this criterion is the question of the externalisation of the causes of relations. It is the result not of internal decisions taken by Armenians, but the consequence of ideological, historical, or political actions of the players directly involved - the Ottoman Empire/Turkey, Azerbaijan, and the USSR/Russia. ${ }^{12}$ Despite the nuances, it can certainly be said that the relationship of interdependence, as well as the perception through the prism of historical analogy and ideological continuity, is indeed emphasised.

The second question was composed as follows: If yes, how significant do you think the connection between the Armenian Genocide and the Nagorno-Karabakh conflict is? This is a consequential question since the answer to it depends on the belief in the existence of a relation between two phenomena. If there is a recognition of existence, then it is possible to assess the significance of the connection/relation. In the online questionnaire, again, the prevailing view was that the connection was significant. $51.4 \%$ of respondents indicated the answer "definitely significant," $37.1 \%$ - significant, $2.9 \%$ - rather significant. The answer "difficult to say" was indicated by $5.7 \%$ of the respondents. $2.9 \%$ of respondents stated

10 Interview V, 8 May 2021.

11 Interview II, 29 April 2021

12 Interview III, 4 May 2021. 
that the connection is insignificant. In the case of the expert interviews, an indicated point was the different intensification of the presence of the discourse linking the two phenomena, depending on the political moment in question. A regularly repeated observation in the interviews was the comparable presence of the genocide narrative as a continuation/ analogy in the second half of the 1980s when the Karabakh Movement began its activities and during the Second Karabakh War. Here the cited example was the use of the term "genocidal" to describe Azerbaijan's intentions towards the Karabakh Armenians during the war. ${ }^{13}$ At the same time, in the historical dimension, the significance of the account is emphasised by references to specific events. In this narrative, the events in the Caucasus in the years 1918-1920 (the Armenian-Turkish war, the offensive of the Army of Islam, the massacres of Armenians in Baku and Shushe), and then the pogroms and aggression against Armenians in Soviet Azerbaijan in the 1980s (Sumgait, Kirovabad, Baku) are an obvious consequence of $1915 .{ }^{14}$ One important element that plays a key role in representations in the public space also emerged in the interviews, namely the question of the survival of the Armenians, threatened by the "Turkic" alliance, whose aim is not only the recapture of Nagorno-Karabakh but also the subjugation of other Armenian lands - the provinces of Syunik and Gegharkunik (around Lake Sevan) and even Yerevan. ${ }^{15}$ Nevertheless, it is necessary to stress that equally clear, especially among younger experts, were the opinions that this is a socially constructed narrative that is not justified by the facts and that Azerbaijani policy towards Nagorno-Karabakh and Armenians, has nothing to do with the genocide of $1915 .{ }^{16}$ Relevance thus comes down to a political exploration of the narrative in which Armenians emphasise the Turkish-Azerbaijani connection and the genocide as a continuation. It is thus a significant connection in political terms.

The third question was composed as follows: In your opinion, does the potential recognition of the Armenian Genocide by Turkey depend on the resolution of the Nagorno-Karabakh conflict? This question is based on the issue of causality. Assuming the existence of a relationship between the Armenian Genocide and the Nagorno-Karabakh conflict, an answer was sought to the question of whether official political and legal recognition of the Armenian Genocide by Republic of Turkey could affect political change in Nagorno-Karabakh. Causally, then, the existence of the interrelation here would be expected to affect political change. Compared to the previous questions, it is not possible to assess causality because of the reception among the respondents. Most respondents answered, "it is difficult to say" $(22,2 \%) .41 .6 \%$ of respondents perceived a correlation between the recognition of the genocide and the resolution of the Karabakh conflict, of which $13.9 \%$ said it definitely exists, $19.4 \%$ said it exists and $8.3 \%$ said it rather exists. $36.2 \%$ of respondents stated that there is no such correlation, including $16.7 \%$ that there is rather not, $13.9 \%$ that there is not and $5.6 \%$ that there is definitely not. In the case of the in-depth interviews, doubts about the actual dependence are significant. In each interview, it was indicated that in the case of the policy of the Republic of Turkey during the thirty years of the independent Republic

13 Interview I, 28 April 2021.

14 Interview II, 29 April 2021, Interview VIII, 8 May 2021.

15 Interview V, 8 May 2021.

16 Interview I, 28 April 2021. 
of Armenia, the initiation of talks on the Armenian Genocide (reconciliation process), was dependent on the issue of ending the Karabakh conflict. The interviewees also stressed that the stance towards this correlation was changing in Armenia over time. The culmination of the attempt to move away from linking the two issues in international politics was the football diplomacy initiative in $2008 .{ }^{17}$ At the same time, it was pointed out that in the second decade of the 21 st century, especially after the Turkish-Azerbaijani rapprochement and the aggravation of the situation around Nagorno-Karabakh after the April 2016 war, this dependency has ceased to be relevant. ${ }^{18}$ It was interesting to point to the interrelation between victim and perpetrator, which by using a minor issue such as the Nagorno-Karabakh conflict was supposed to change the perception of Armenians as victims of the genocide of 1915 . The use of the image of injustice suffered by the Armenians of Azerbaijan was to reassure international public opinion that the events of 1915 were not an unequivocally one-sided act of genocide committed against the Armenians. It was to be one of the elements of a multidimensional negationist policy. ${ }^{19}$ Some of the interviewees indicated that this correlation does not exist, regardless of how the Nagorno-Karabakh conflict would be resolved. This is supposedly due to the all too important place that denialism of the Armenian Genocide holds in the historical culture and identity politics of the Turkish Republic. Recognition of the genocide would have to mean a complete redefinition, which is impossible under the current government. ${ }^{20}$ Another element that has been pointed out as giving rise to doubts is the question of economic and political pressure. It has been pointed out that only political pressure from superpowers or a strong economic necessity can force Turkey to consider discussing genocide, but that the Nagorno-Karabakh conflict is not such an issue. ${ }^{21}$

The fourth question was composed as follows: In your opinion, is the potential resolution of the Nagorno-Karabakh conflict dependent on Turkey's recognition of the Armenian Genocide? Also, this question is related to the question of casuality, in reverse order. Casually, then, political change in feedback would affect the existence and form of the relationship between the two phenomena. Also, in the case of this question, reversed from the previous one, the answers were varied and ambiguous. The largest number of respondents $(25 \%)$ indicated that the potential recognition of the Armenian Genocide by Turkey could not influence the resolution of the Nagorno-Karabakh conflict (answer "no"). Additionally, $2.8 \%$ stated that causality in this relationship is definitely not there, and $11.1 \%$ that it is rather not there. Nevertheless, this represents $38.9 \%$ of the responses, while $55.5 \%$ of the respondents were of the opposite opinion (answer "definitely yes" - 13.9\%, "yes" 19.4\%, "rather yes" - 22.2\%). 5.6\% of the respondents indicated "difficult to say." In the case of expert opinion, they are also ambiguous. Although dependency, as in the case of the earlier question, is emphasised, the prevailing view is also that there is no potential causality. The Nagorno-Karabakh conflict is perceived as a marginal element of Turkish policy and therefore cannot be seen as dependent on the recognition of the genocide, importantly, regardless

17 Interview III, 4 May 2021. Also Alexander Iskandaryan, “Armenian-Turkish Rapprochement: Timing Matters," Insight Turkey 11, no. 3 (2009): 37-44.

18 Interview IV, 8 May 2021, Interview VIII, 8 May 2021.

19 Interview VI, 8 May 2021.

20 Interview III, 4 May 2021. Interview V, 8 May 2021.

21 Interview X, 14 May 2021, Interview XI, 12 May 2021. 
of how the solution would look (whether it would be in favour of Armenia or Azerbaijan). Importantly, in this case, the experts more clearly emphasize that the Nagorno-Karabakh issue is related to the geopolitical situation in the Caucasus, while the issue of recognition of the Armenian Genocide is more of an issue of internal Turkish politics. ${ }^{22}$ Thus, recognition of the genocide does not necessarily entail facilitating the reconciliation process around Nagorno-Karabakh. The opposite statement also appeared in the interviews. According to experts, the recognition of the genocide by Turkey, and thus the normalization of relations with Armenia, could be associated with the reduction of Azerbaijan's aggressive rhetoric and policy towards the resolution of the Nagorno-Karabakh issue. At the same time, it would be a bargaining chip for Yerevan in negotiations with Baku, even if recognition in this context would be understood only as a right to memory and would not be linked to concrete consequences such as demands for compensation. ${ }^{23}$

The fifth question was composed as follows: In your opinion, does Armenia have a policy that emphasizes the connection between the commemoration of the Armenian Genocide and the Nagorno-Karabakh conflict? It is therefore a question about the politicisation of the relationship between the Armenian Genocide and the Nagorno-Karabakh conflict. From the level of recognition of the existence of the relationship itself, considerations are already shifted to the issue of exploitation, and thus instrumentalization as a concrete technology of power. In this case, in the closed questionnaire, $19.5 \%$ of the respondents answered that such a policy was in place, with only $2.8 \%$ answering "yes" and $16.7 \%$ "rather yes". $2.8 \%$ of respondents said they "don't know" and $8.3 \%$ said it was "difficult to say." The existence of such a policy was assessed unequivocally negatively by $69.7 \%$ of respondents. Of these, $13.9 \%$ said that Armenia "rather" does not have such a policy, 44.4\% that it does not, and $11.1 \%$ that it "definitely" does not. Among experts, opinion on this issue is unequivocal there is no official policy that combines both issues in domestic and foreign policy. ${ }^{24} \mathrm{How}-$ ever, there was also an indication that while there is no such official policy, there is potential for it to be conceptualised and used as a tool in foreign policy. ${ }^{25}$ Nevertheless, experts stress that there is no doubt that in the statements of the most important Armenian politicians, especially from the time of the Second Karabakh War, analogies and narratives indicating a kind of continuity appeared regularly. This was mainly due to Turkey's involvement on the side of Azerbaijan. Experts emphasise, however, that the use of correlations, both as analogies and continuations, was an ad hoc political exercise and there are no grounds to presume the existence of a specific political doctrine. ${ }^{26}$ According to experts, political linking of these issues in the dimension of rational use of resources may have dual consequences. On the one hand, it may lead to a deeper antagonization of relations with Turkey and thus be dangerous for Armenia (realist approach). On the other hand, the political linking is necessary for ethical reasons, as there is historical and ideological evidence that shows that the correlation between the experience of genocide and the Nagorno-Karabakh conflict

22 Interview II, 29 April 2021, Interview XI, 12 May 2021.

23 Interview X, 14 May 2021, Interview I, 28 April 2021, Interview V, 8 May 2021.

24 Interview II, 29 April 2021, Interview VI, 8 May 2021, Interview I, 28 April 2021, Interview IX, 8 May 2021, Interview X, 14 May 2021, Interview XI, 12 May 2021, Interview V, 8 May 2021.

25 Interview VIII, 8 May 2021, Interview V, 8 May 2021.

26 Interview I, 28 May 2021, Interview VII, 8 May 2021. 
is real (ethical approach). ${ }^{27}$ At the same time, some experts do not doubt that the linking of the two issues is socially constructed because of the belief of many Armenians that there is no difference between Azerbaijanis and Turks at the ethnic, national, and cultural level. This makes the correlation between the two phenomena play a significant role at the level of primary "the political." 28

The sixth question was composed as follows: If yes, do you think that linking the Armenian Genocide to the Nagorno-Karabakh conflict is the right policy direction for Armenia? This is a consequential question. It depends on the question of recognising whether the relationship of the Armenian Genocide and the Nagorno-Karabakh conflict is a technology of power used in Armenia. This is an evaluative question and implicitly raises the ethical dimension of the relationship under study. In the questionnaire, $12.5 \%$ of respondents indicated the answer "don't know" and 18.8\% answered "difficult to say." For 31.3\% of respondents this is not a valid policy, of which $3.1 \%$ answered "definitely not," $18.8 \%$ answered "no" and 9.4\% answered "rather not." At the same time, 37.5\% of respondents indicated that the correlation policy was correct, of which $21.9 \%$ answered "yes" and $15.6 \%$ "rather yes." Then, the dichotomy identified by experts regarding the validity of such policies and the conflict between ethical and realistic action is evident in the perception of respondents. Differing opinions are also expressed by experts. Some point out that such a merger works against Armenia and should not take place. ${ }^{29}$ Experts also point out that the harmfulness of the policy of merging the two phenomena is also related to the fact that two separate narratives are created in Armenian politics - for internal and external needs. In external politics, the message is carefully controlled in which the two phenomena are separated from each other, while in internal politics there is a merger, and Nagorno-Karabakh is part of the Greater Armenia project that includes the territories of Western Armenia (East of Anatolia), so separation is impossible. ${ }^{30}$ At the same time, some experts point out that the development of the situation in Nagorno-Karabakh in the 1920s is a consequence of the actions of the Young-Turks and a direct result of the Bolsheviks' relations with the Kemalists, so from an ethical and axiological point of view, the pursuit of such a policy would be most appropriate. ${ }^{31}$ The legitimacy of such a policy is also demonstrated from a more rational perspective as an opportunity to use the trauma and experience of genocide and loss as a tool in international politics. ${ }^{32}$

The seventh question was composed as follows: In your opinion, has Armenian policy towards the relationship of recognition and commemoration of the Armenian Genocide and the Nagorno-Karabakh conflict changed after the change of power in 2018? The question looks at the change over time in the approach to the relationship of the two phenomena. If 2018 and the so-called Armenian Velvet Revolution were the last significant political change, the question aims to test the potential change in the use of the relationship of the memory of the Armenian Genocide and the Nagorno-Karabakh conflict in current politics.

\footnotetext{
27 Interview IV, 8 May 2021, Interview VII, 8 May 2021 Interview III, 4 May 2021.

28 Interview VI, 8 May 2021.

29 Interview IV, 8 May 2021.

30 Interview VI, 8 May 2021, Interview IX, 8 May 2021.

31 Interview II, 29 April 2021, Interview III, 4 May 2021.

32 Interview I, 28 April 2021, Interview VII, 8 May 2021.
} 
Thus, the question is meant to indicate the relevance of an important assumption of the research, namely the belief in the processual dynamics of instrumentalization and its change, not only over time but also in context. For this question, $2.8 \%$ of the respondents answered, "don't know" and 8.3\% "difficult to say." $36.1 \%$ of respondents believe that after 2018, a change in the policy of combining the two phenomena has not occurred. Of this, $2.8 \%$ said it "definitely" did not occur, $11.1 \%$ said it did not occur and $22.2 \%$ said it "rather" did not occur. The opposite view was held by $52.7 \%$ of those questioned, of which $8.3 \%$ believe that it has "definitely" occurred, $25 \%$ that it has occurred and $19.4 \%$ that it has "rather" occurred. Nuanced and ambiguous assessments, on the other hand, were presented by experts. An element highlighted is the issue of uncertainty about the direction of change in the real dimension, i.e., the actual blaming of Nikol Pashinian and his associates for the defeat in the Second Nagorno-Karabakh War and causing Azerbaijan and Turkey to gain a narrative advantage. At the same time, it is questioned whether there is any indication of a political change of course in the context of the correlation of the two phenomena. ${ }^{33}$ According to some experts, this policy has not changed because of the transformations initiated by the so-called Velvet Revolution in 2018. Nevertheless, also in these distanced opinions, there is a conviction about the political use of the narrative linking the two phenomena during the armed phase of the conflict in 2020. At the same time, it has also been highlighted those statements linking both issues, for example in the context of the lifting of the border blockade with Turkey conditional on the resolution of the Nagorno-Karabakh conflict, have started to reappear in the discourse in Turkey. ${ }^{34}$ An important observation made in the interviews is the question of the change of form (the language of politics) while there is no change of content in the context of combining the two phenomena. ${ }^{35}$ Some experts also point out that, at the declarative level, there has indeed been an indication since 2018 of a desire to make changes in the approach to both phenomena considered both singularly and in combination. Nevertheless, it was emphasised that the change was not finally realised and remained only at the level of ideas. The issues of democratisation and the fight against corruption, which dominated the actions of Nikol Pashinian's government before the 2020 war, were pointed out as the reason for the lack of implementation of the proposed policy. ${ }^{36}$ An important aspect highlighted in the context of the 2018 political shift was the issue of the desire to separate Armenian politics regarding the two phenomena and the expectations of the Armenian diaspora in the West, which expected a more decisive combination of narratives about the Armenian Genocide and the Nagorno-Karabakh conflict. ${ }^{37}$ It is important to emphasise that if the thesis of a redefinition of the post-2018 policy is accepted, the change concerns only the issue of the approach to the potential resolution of the Nagorno-Karabakh conflict, while the approach to the commemoration and recognition of the Armenian Genocide remains unchanged. ${ }^{38}$

The eighth question was composed as follows: If yes, how would you rate the extent to

33 Interview XI, 12 May 2021, Interview III, 4 May 2021.

34 Interview V, 8 May 2021, Interview VII, 8 May 2021, Interview VI, 8 May 2021, Interview IV, 8 May 2021.

35 Interview V, 8 May 2021, Interview II, 29 April 2021.

36 Interview X, 14 May 2021, Interview VIII, 8 May 2021.

37 Interview X, 14 May 2021.

38 Interview I, 28 April 2021. 
which the use of narratives about the relationship between these issues has intensified after 2018? The question arising from the previous one concerns the assessment of the degree of intensification (or lack thereof) in the process of instrumentalization of the relations of the studied phenomena in politics. In this question, significantly, the highest percentage of "difficult to say" responses of 33.3\% appeared. At the same time, 36.4\% of respondents said that the intensity of the use of linked narratives had increased, of which $15.2 \%$ said it had "definitely increased," 9.1\% said it had "increased," and 12.1\% said it had "rather increased." $21.2 \%$ of respondents felt that the use of linked narratives had decreased, of which $9.1 \%$ of respondents said, "rather decreased," $3 \%$ said "decreased" and $9.1 \%$ said "definitely decreased". In the case of the expert interviews, one of the elements highlighted in the case of this question was the doubt towards the intentionality of linking both phenomena for political purposes. The argumentation was based on the statement that what is obvious and understandable for experts, for example, academic experts, i.e., the obvious connection between the Armenian Genocide and the Nagorno-Karabakh conflict, is not necessarily understandable by politicians. ${ }^{39}$ It is extremely important to point out that the intensified use in one narrative, was primarily due to the increasingly aggressive policies of Azerbaijan and Turkey towards Armenia, and ultimately the armed conflict in 2020. At the same time, an additional connection was also indicated in the context of the "cultural genocide" affecting the Armenian heritage in Nakhichevan. ${ }^{40}$

The ninth question is composed as follows: In your opinion, should the issue of resolving the Nagorno-Karabakh conflict be combined with the issue of the Armenian Genocide? This is a crucial question. It concerns the legitimacy, validity, and correctness of using a combination of both narratives in Armenian politics. It thus intertwines questions of pragmatic necessity, the ethics of such action, and value judgements on issues that are extremely important components of collective memory and collective identity. For this question, 58.4\% of those asked indicated that the two phenomena should be combined. $13.9 \%$ of respondents indicated a "definitely yes" answer, 30.6\% a "yes" answer and 13.9\% a "rather yes" answer. The opposite opinion was held by $41.6 \%$ of the respondents, of which $22.2 \%$ answered "rather no," 16.7\% "no" and 2.7\% "definitely no." An important aspect highlighted in the expert interviews was the issue of the need to separate academic and expert knowledge from the use of history by politicians. According to the experts, knowledge about the connection based on analogy and continuity between the phenomenon of the Nagorno-Karabakh conflict and the phenomenon of the Armenian Genocide should be widely disseminated, which does not mean that at the same time it should be subject to manipulation, instrumentalization and ideologization for the achievement of specific political goals, whether defined as internal or external. ${ }^{41}$ The highlighted negative consequence of combining the two phenomena is the granting of a narrative side to Turkey in the Karabakh conflict, which is in clear contradiction to the Armenian raison d'état. ${ }^{42}$ For some experts, the two issues should be separated, since their combination at the level of political realism has bad consequences for

39 Interview II, 29 April 2021, Interview VII, 8 May 2021, Interview III, 4 May 2021.

40 Interview I, 28 April 2021, Interview V, 8 May 2021.

41 Interview V, 8 May 2021, Interview VIII, 8 May 2021.

42 Interview VI, 8 May 2021, Interview II, 29 April 2021. 
Armenia's foreign policy goals, negatively affecting both the issue of a potential settlement of the Nagorno-Karabakh conflict in favour of Yerevan and the promotion of recognition of the Armenian Genocide. ${ }^{43}$ In some cases, benefits that could be described as economic were highlighted as those that could serve as positive arguments for combining the two narratives. ${ }^{44}$ In addition to economic arguments, ethical and axiological ones were also raised, stressing the right of Armenians to remember and recall their history, which at the same time justifies the validity of combining the two phenomena. ${ }^{45}$ The question of the inevitability of discursive fusion arising from the demand on a social level in a traumatised society also emerges in the interviews. In this case, the question of the rightness and correctness of the chosen political direction does not play a role. ${ }^{46}$ At the same time, among experts who support combining both narratives, there is the question of the rightness of such an action in the perspective of international law and building the image of Armenia and Armenians as victims, juxtaposed with the perpetrators, i.e., Turkey and Azerbaijan, who are not separated in such a narrative. ${ }^{47}$

\section{Representations of the Past in the Public Space}

In the post-Soviet space, the relevance of public representations of memory was considered from multiple perspectives. ${ }^{48}$ Kiril Stanilov, among others, has written about the space of the post-socialist city and the role that representations of memory play in it as elements of the consolidation process of transformation. ${ }^{49}$ Also museums as both places of representation of the past and spaces of persuasion were analysed in the context of the former USSR and the South Caucasus. ${ }^{50}$ In Armenia, reflections on public representations of the communist past and their ambiguous legacy were undertaken. ${ }^{51}$ An important voice in the analysis of public spaces of memory in an anthropological perspective in Armenia itself is the work of Harutyun Marutyan. ${ }^{52}$ Representations of the past in public (understood as political) space, perform the function of places of memory. They are at the same time a representation of the

43 Interview III, 4 May 2021, Interview IV, 8 May 2021.

44 Interview X, 14 May 2021.

45 Interview IX, 8 May 2021.

46 Interview VII, 8 May 2021.

47 Interview I, 28 April 2021.

48 Julie Fedor, "Memory, Kinship, and the Mobilization of the Dead: The Russian State and the 'Immortal Regiment" Movement," in War and Memory in Russia, Ukraine and Belarus, ed. Julie Fedor et al., Palgrave Macmillan Memory Studies (Cham: Springer International Publishing, 2017), 307-345; Benjamin Forest and Juliet Johnson, "Monumental Politics: Regime Type and Public Memory in Post-Communist States," Post-Soviet Affairs 27, no. 3 (2011): 269-288.

49 Kiril Stanilov, The Post-Socialist City: Urban Form and Space Transformations in Central and Eastern Europe after Socialism (Dordrecht: Springer, 2010).

50 Clive Gray, The Politics of Museums (London: Palgrave Macmillan, 2015); Museums and Sites of Persuasion: Politics, Memory and Human Rights, eds. Joyce Apsel, Amy Sodaro (London, New York: Routledge, 2019); Malkhaz Toria, "Between Traditional and Modern Museology. Exhibiting National History in the Museum of Georgia," in Museums and Sites of Persuasion. Politics, Memory and Human Rights (London, New York: Routledge, 2020), 39-55.

51 Gayane Shagoyan, "Between Memory and Memorial: Anastas Mikoyan and 'Social Lustration' in Armenia," Caucasus Analytical Digest 80 (2016): 2-5.

52 Marutyan, Iconography of Armenian Identity. 
official discourse towards the past and play a creative role for the binding narratives. ${ }^{53}$ What is nuanced, but clearly manifested in the in-depth interviews and the online questionnaire, is represented very clearly in the public and individual memorials and realms of memory. Representation (of memory) in this context is defined according to Paul Ricoeur's conception, in which representation can be interpreted in three distinct senses. Firstly, representation is thus the representation of the past in the present. Secondly, representation is the reappearance in the space of discourse of what has hitherto been absent. Third, representation is also a reference for the historian. ${ }^{54}$ The following are representations of the past in space, indicating a discursive connection between the phenomenon of the memory of the Armenian Genocide and the phenomenon of the Nagorno-Karabakh conflict.

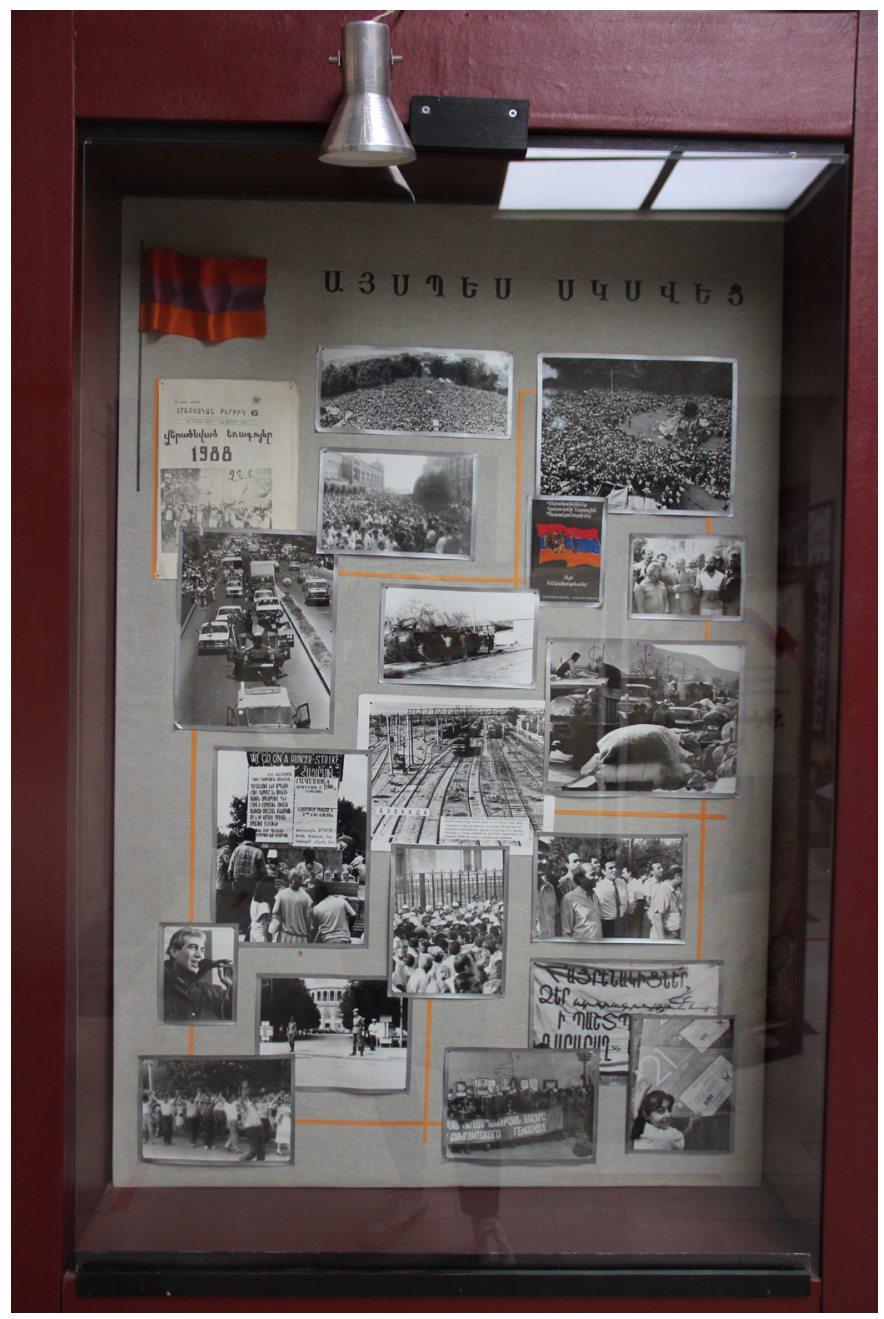

53 Andrzej Szpociński, "Miejsca Pamięci (Lieux de Memoire)," Teksty Drugie 4 (2008): 11-20; Pierre Nora, "Between Memory and History: Les Lieux Des Memoires," Representations 26 (1989): 7-24.

54 Paul Ricœur, Pamięć, Historia, Zapomnienie, trans. Janusz Margański (Kraków: UNIVERSITAS, 2012), 252-253. 


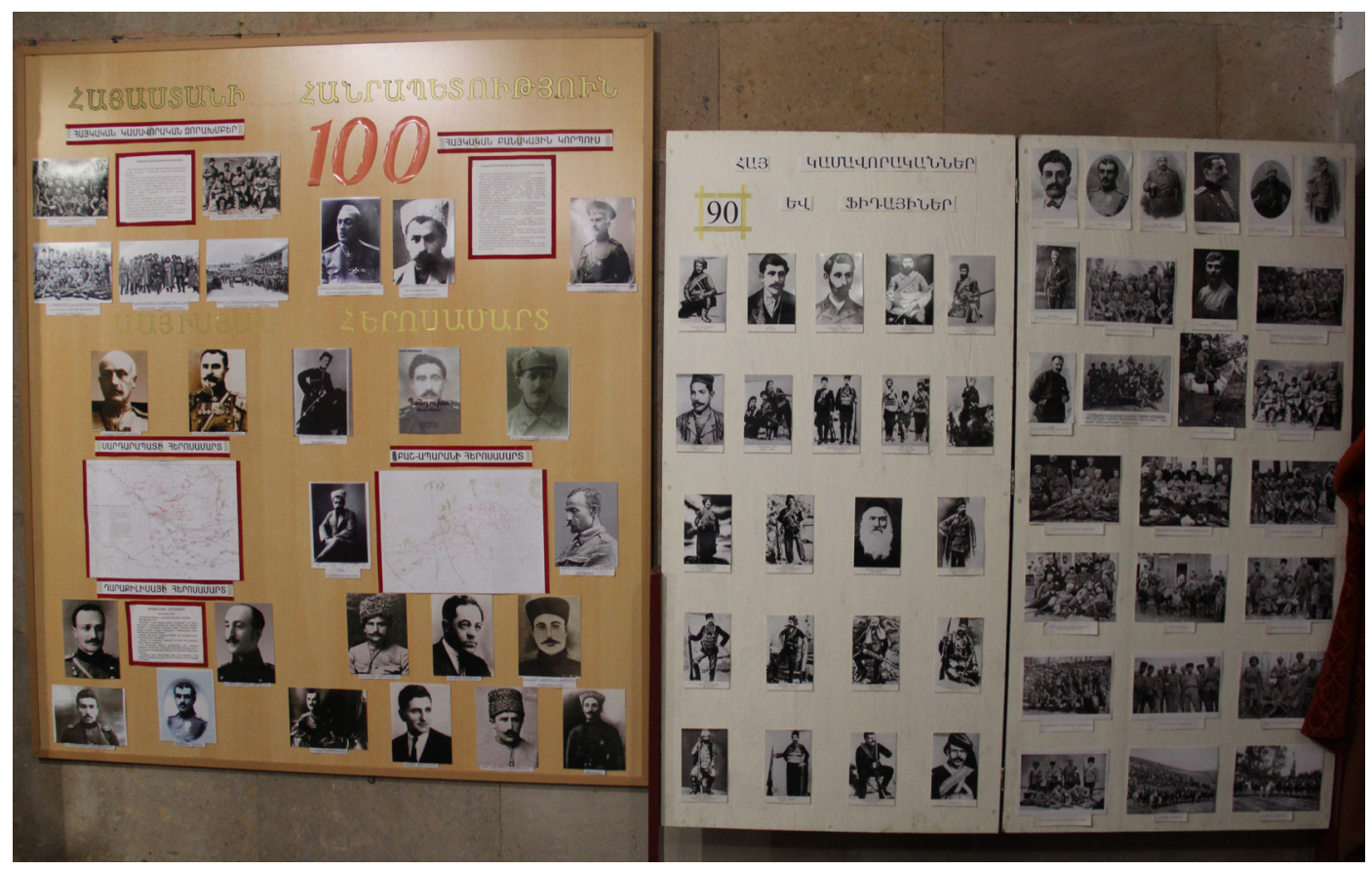

Photo I and II. Exposition of the Ministry of Defence of the Republic of Armenia Mother Armenia Military Museum in Yerevan. Author's photo, Yerevan, 07.05.2021

Photos I and II show representations at the Mother Armenia Military Musuem in Yerevan. According to information, the museum was officially opened as a memorial on 29 November 1950, on the 30th anniversary of the establishment of Soviet power in Armenia. In front of the entrance to the complex, there is a pedestal, on which a sculpture of Joseph Stalin was placed. Because of the "Khrushchev thaw," the monument was removed, and in its place, the Mother-Armenia monument was established in 1970. The interior of the complex was dedicated to the sacrifice of the Armenian people made during the Great Patriotic War. In 1995 the complex came under the jurisdiction of the Ministry of Defence of the Republic of Armenia and was divided into two parts - in the basement there is an exposition dedicated to the Great Patriotic War, and on level zero there is an exposition "The War of Liberation in Artsakh." The first significant narrative element to note is the equating of the significance of two historical events - the Great Patriotic War and the First Nagorno-Karabakh War. The contradiction of such a combination - the Soviet defence against the Nazi invasion and the guerrilla war on the ruins of the empire - is only apparent. The manner of exposition points to similar mechanisms and structures shaping the narratives. The individual heroic attitudes of Armenians participating in both conflicts are highlighted. In the case of the exhibition on Nagorno-Karabakh, the heroic attitudes of Armenians from the diaspora, such as Monte Melkonian, who decided to support the Armenian cause, are emphasised. This also shapes the element of historical continuity. Ideological underpinnings play no role concerning national identity in practice. Nor does it matter what the dispute was about and whether the struggle took place in lands considered Armenian or in distant Europe. These similar mech- 
anisms and structures of commemoration indicate the presence of a historical analogy. It is marked in the metaphorical figures used for presentation. As during the Great Patriotic War, the figurative basis for the representation of the First Nagorno-Karabakh War is the idea of sacrifice and martyrdom, often at the ultimate expense of lives. Both narratives are also linked by the issue of liberation and throwing off unjustly imposed shackles, as well as the communal - national-ethnic - effort that must be made to preserve identity. What unites the two narratives shaping a kind of historical continuity at the narrative level is the question of survival. Sacrifice and martyrdom must be made for the Armenian ethnic and national identity to survive. The survival of the nation (group identity) and the individual testimonies of survivors that function through this are the basis for the commemoration and the struggle for recognition of the Armenian Genocide. Strengthened as a form of living history by the experience of the Great Patriotic War, it had a chance to be preserved in the next generation, and then to be realised now of turning point and the necessity to take up the struggle for Nagorno-Karabakh. ${ }^{55}$

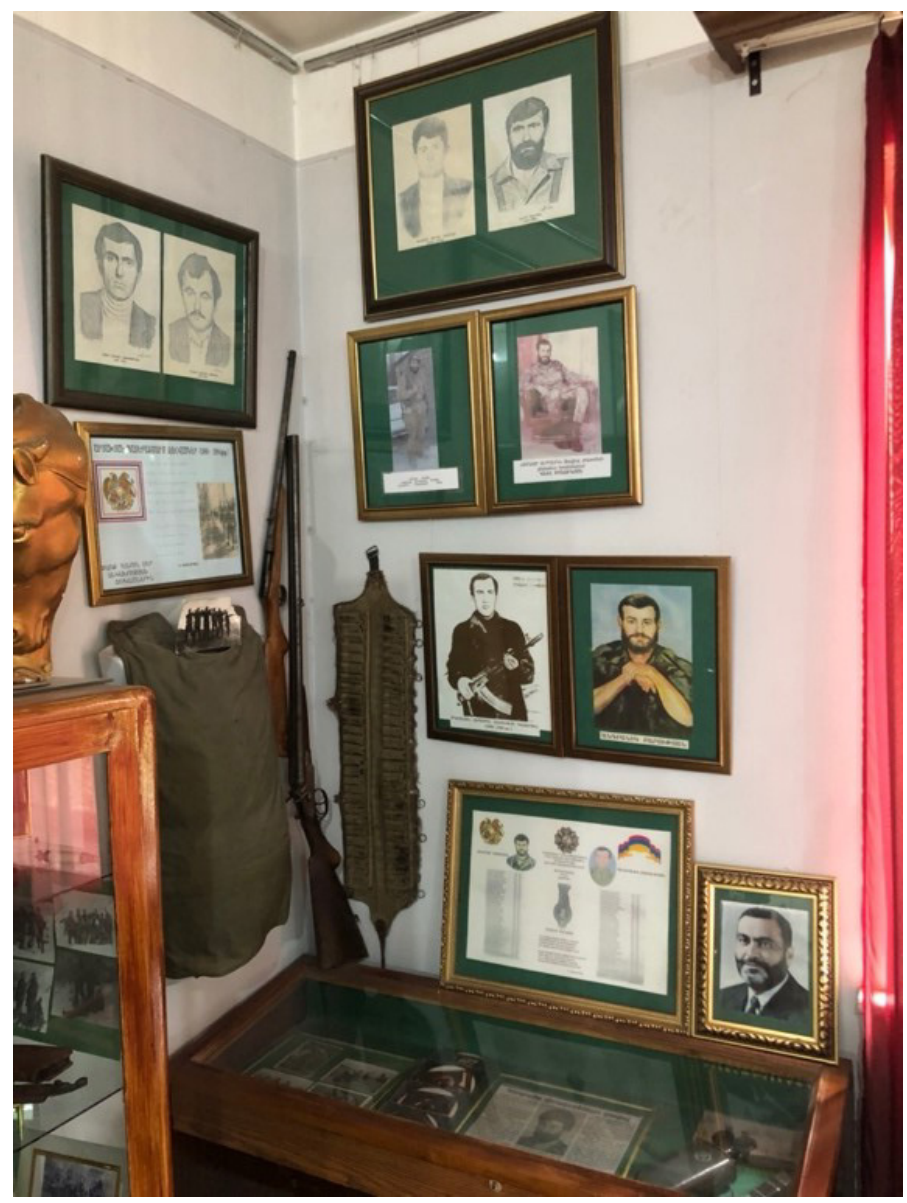

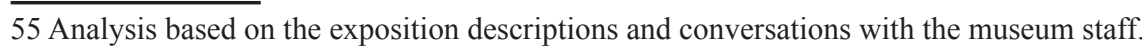




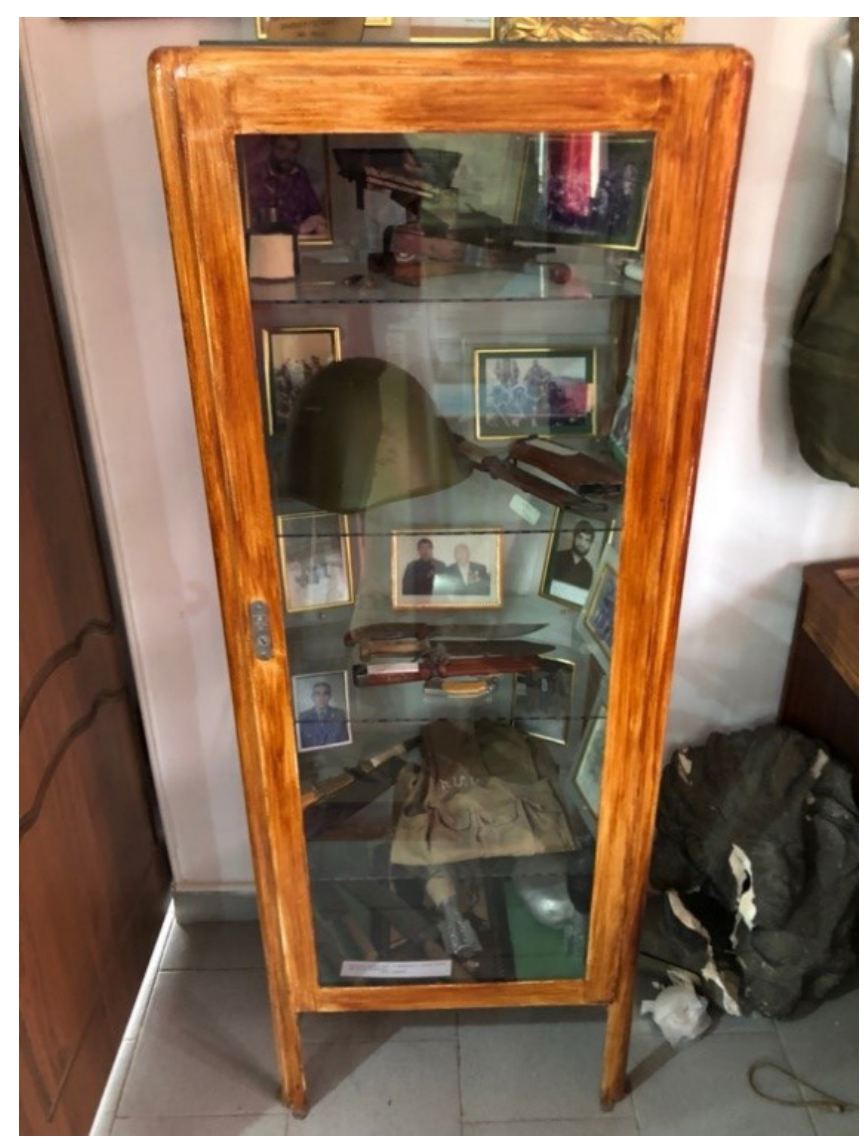

Photo III and IV. Exposition of Fedayi Museum in Yerevan. Author's photo, Yerevan, 01.05.2021

Photos III and IV show museum representations at the Museum of the Armenian Fedayi Movement in Yerevan. This is a small, private museum created through the efforts of Ilyich Beglarian and named after General Andranik (Ozanian), one of the most important commanders of the Armenian fedayi movement at the turn of the 20th century. It is in the vicinity of the National Pantheon in Yerevan. It was established in 1995, then closed after the building was privatised and reopened in 2006. The fedayi movement emerged in the 1880 s as self-defence groups and irregular militias whose main purpose was to protect Armenians in Western Armenia from Kurdish armed groups, Hamidian militias and Ottoman troops. Attacks on Armenian peasants intensified during the reign of Sultan Abdul Hamid II. Fedayi units' activity was particularly significant during the Hamidian massacres, the Zeytun Rebellion, the Defence of Van, and the Sasun Resistance. An additional goal of the fedayi that formed over time was to obtain autonomy for Armenians in the Ottoman Empire or independence. ${ }^{56}$ Part of the exhibition in the museum (visible in the photos) is devoted to the "successors" of the fedayi, this time protecting the Armenian territory of Nagorno-Kara-

56 Richard G. Hovannisian, "The Armenian Question in the Ottoman Empire 1876-1914," in The Armenian People from Ancient to Modern Times. Foreign Dominion to Statehood: The Fifteenth Century to Twentieth Century, ed. Richard G. Hovannisian, vol. II (London: Macmillan, 1997), 203-238. 
bakh from the Azerbaijani threat. The issue of the enemy is equated in representation by the analogy of Turks and Azerbaijanis. However, the question of teleology is also dealt with - like the fedayi, the participants in the First Karabakh War fight to defend the threatened Armenians of Nagorno-Karabakh. At the same time, a second objective is also revealed, namely the desire to liberate territories considered to be occupied by foreigners. During the First Nagorno-Karabakh War, there was a regiment named after Andranik, and the attitude of the general himself, and other fedayi, was meant to be inspirational for young Armenians reaching the front. ${ }^{57}$ At the same time, it is worth pointing out an even more important connection. The greatest heroes of modern Armenian history are military commanders meritorious in a theoretically lost cause - like Andranik and Vazgen Sargsyan, a commander from the First Karabakh War. Thus, the reference to specific figures is a historical analogy of a similar struggle, and incidentally also a continuation of the "Turks" clash. At the same time, as the exhibition points out, also for General Andranik Karabakh was an important part of the Armenian liberation struggle, which further highlights the analogy between the two narratives. ${ }^{58}$

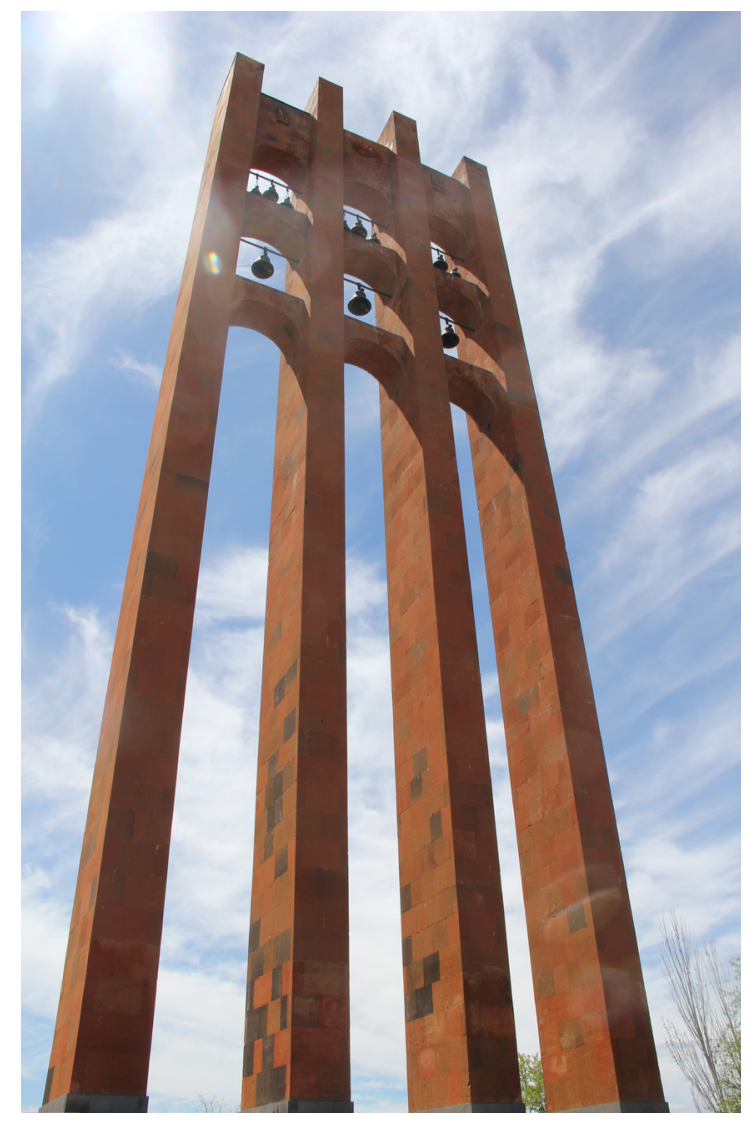

57 Patrick Gore, Tis Some Poor Fellow's Skull: Post-Soviet Warfare in the Southern Caucasus (iUniverse, 2008), 17-18.

58 Analysis based on the exposition descriptions and conversations with the museum staff. 


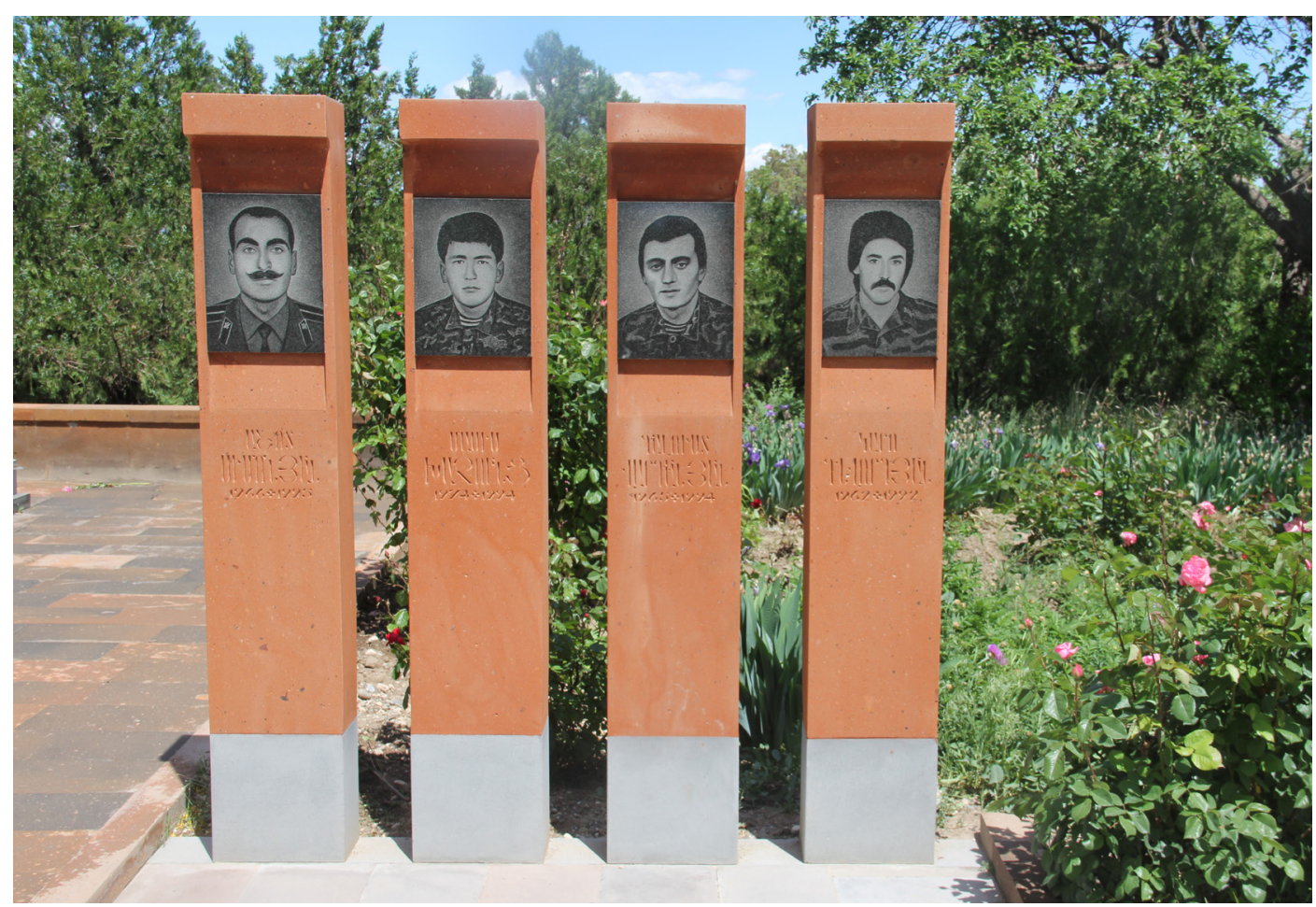

Photo V and VI. Sardarapat Monument. Author's photo, Sardarapat, 10.05.2021.

Photos V and VI show public representations at the memorial site of the monument commemorating the Battle of Sardarapat which took place between 22-26 May1918 during the Caucasus Campaign of WWI between Armenian forces and the Ottoman army which invaded the territory of Eastern Armenia. The memory of the Battle of Sardarapat was marginalised in Soviet historiography until the 1960s. Only with the violent protests in Armenia in 1965, on the 50th anniversary of the Armenian Genocide, did the Soviet authorities agree to create a memorial at the site where the battle took place. The official opening of the memorial took place in 1968, on the 50th anniversary of the battle..$^{59}$ Today, the Battle of Sardarapat and the Armenian offensive at Bash-Aparan and the defence of Karakilisa (today's Vanadzor) are an important part of Armenian memory. Glorification is not only linked to the commemoration of the military victory that led to the establishment of the First Republic of Armenia on May 28, 1918. The Battle of Sardarapat is considered the decisive moment of the Caucasus Campaign, which not only halted the Ottoman offensive into the Caucasus, slowing the march on Baku, but also prevented the final annihilation of the Armenians. ${ }^{60}$ In the mid-1990s, after the end of the First Nagorno-Karabakh War, official commemorations of Armenian soldiers who fell during the war were established on the memorial grounds. They have a specific character, combining individual remembrance in the form of tombstones with the politics of remembrance linking the issue of Armenian defence

59 Razmik Panossian, The Armenians: From Kings and Priests to Merchants and Commissars (New York: Columbia University Press, 2006), 251.

60 Christopher J. Walker, Armenia : The Survival of a Nation (London: Croom Helm, 1980), 254-255. 
against the Ottoman offensive with the struggle for the liberation of Nagorno-Karabakh. The most prominent element in collective memory, therefore, is the question of continued resistance to Turkish aggression resulting in the Armenian Genocide in Western Armenia, which, thanks to a self-sacrificing defence, was not extended to Eastern Armenia.

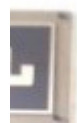

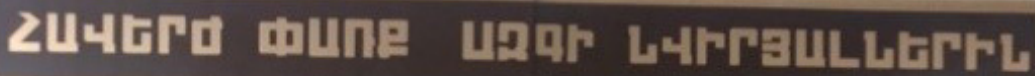

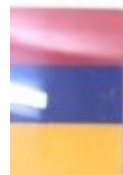

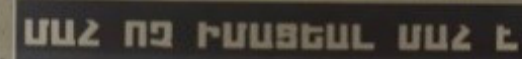

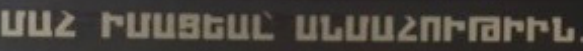
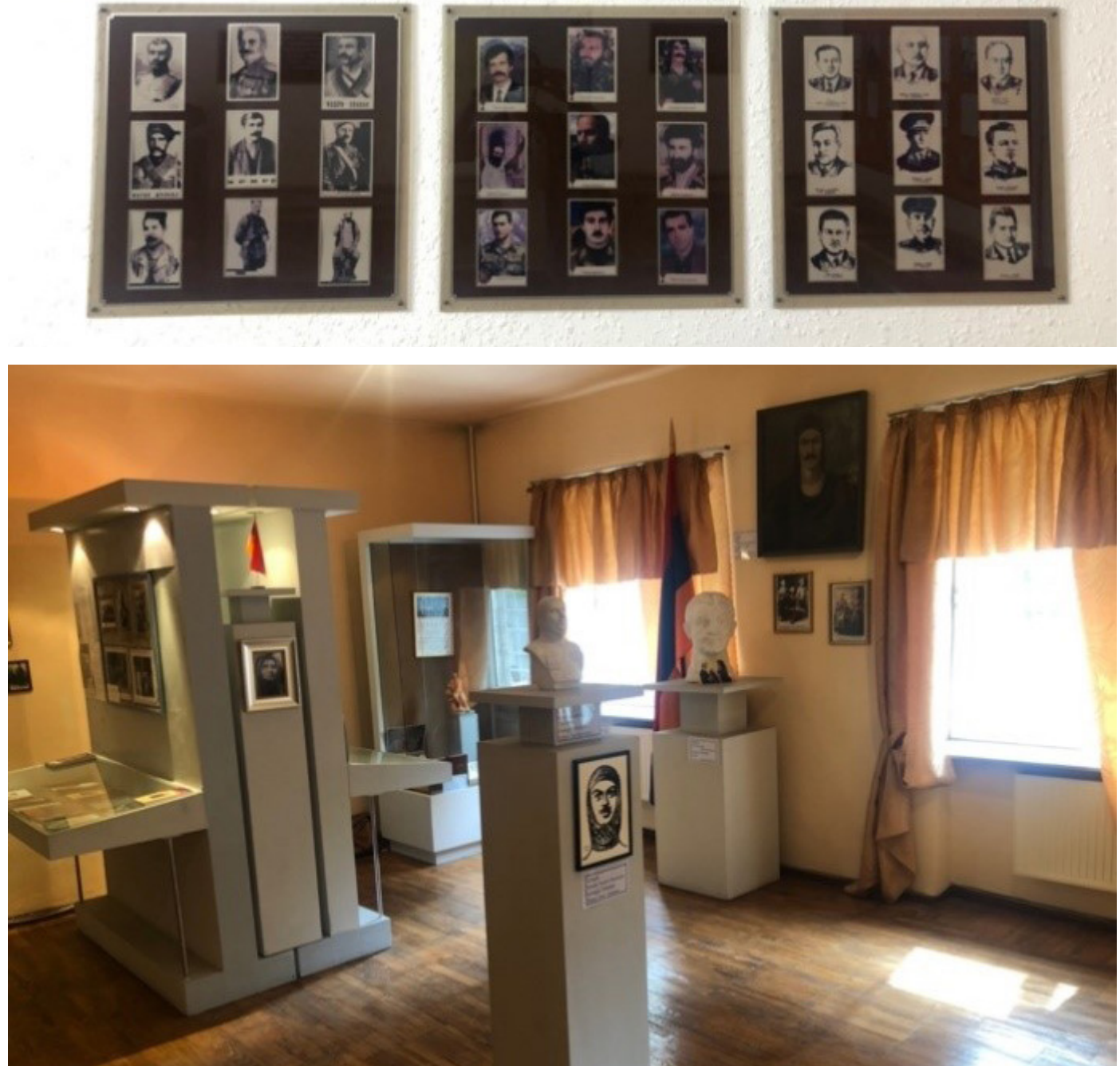

Photo IX and X. Garegin Nzdeh School and Museum. Author's photo, Yerevan 07.05.2021. 
Photo IX and X shows representations in everyday life at the Garegin Nzdeh School and Museum in Yerevan. School No. 12 named after Garegin Nzdeh is in the Yerevan district of Shengavit, near the square of the same name. The school hosts a small museum whose exhibition depicts the life and work of Garegin Nzdeh, an Armenian military officer and politician. He was associated with the Armenian Revolutionary Federation, being one of the most important military commanders of the First Republic of Armenia. After the Soviet invasion of Armenia in November/December 1920, disagreeing with the plan to incorporate his native Nakhichevan and Nagorno-Karabakh into Soviet Azerbaijan, he formed the Republic of Mountainous Armenia in Zangezur, fighting against the Soviets until July 1921. He then carried out organisational activities for the ARF. During WWII, he was a supporter of cooperation with the Axis states. ${ }^{61}$ The figure of Nzdeh, repressed in the Soviet Union, is also significant because, paradoxically, his openly anti-Soviet and anti-Ottoman stance is different from the standard more nuanced approach to the Soviet legacy in Armenia. At the entrance to the school, there is a significant plaque that highlights the historical continuity between the fedayi movement, the founders of the First Republic of Armenia and the fighters of the First Karabakh War. In addition to highlighting elements indicated in the earlier case of representation, in this case, it is interesting to build a bridge between Eastern and Western Armenia, of which Garegin Nzdeh was a representative, fighting against the Ottoman Empire in the Bulgarian army during the Balkan Wars, as well as against Soviet Russia in Zangezur. This representation thus becomes important due to the fact of linking anti-imperial resistance to oppression, of which the Azerbaijani policy towards Karabakh is also a contemporary manifestation in the narrative.

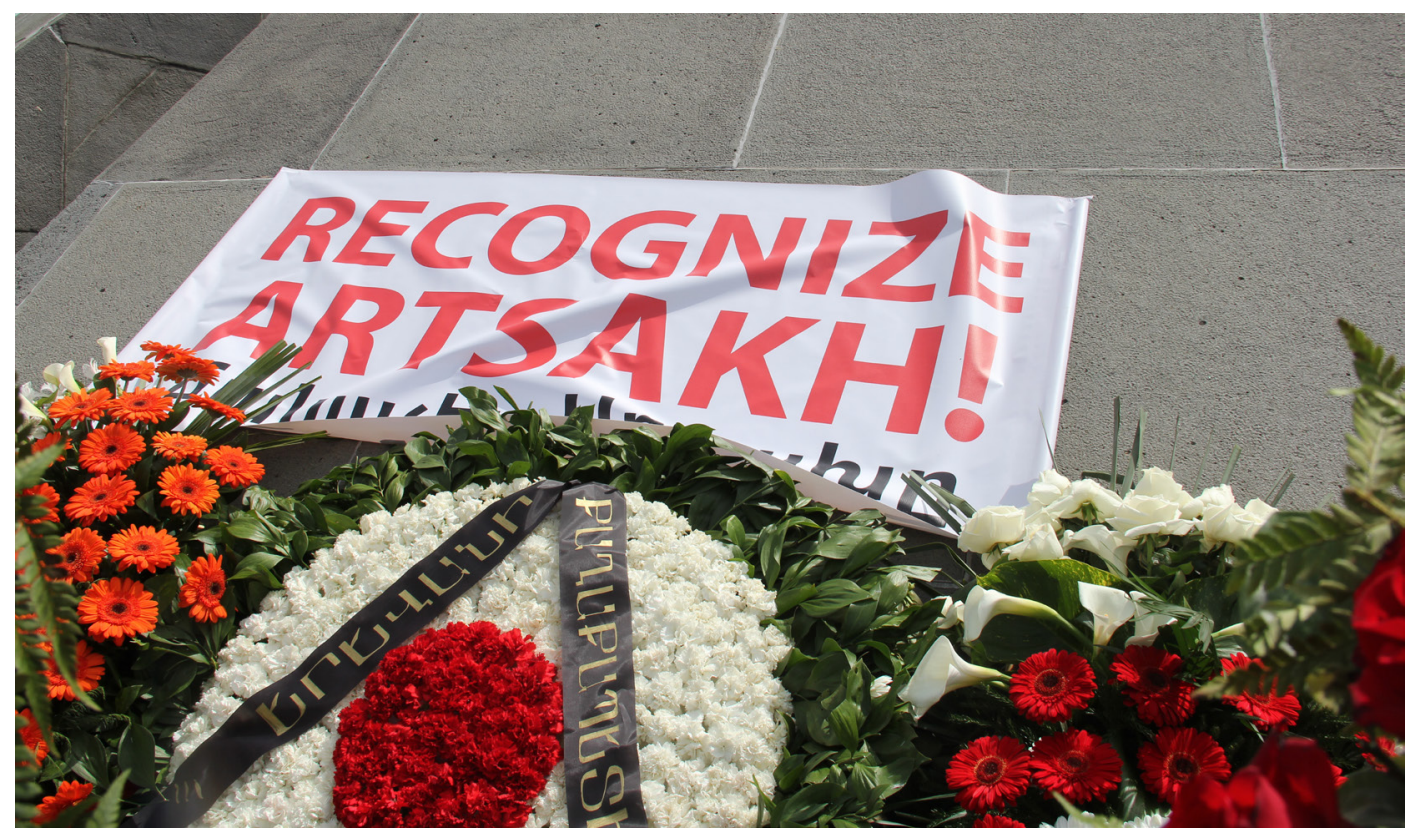

61 Razmik Panossian, “The Past as Nation. Three Dimensions of Armenian Identity,” Geopolitics 7, no. 2 (2002): 132 . 


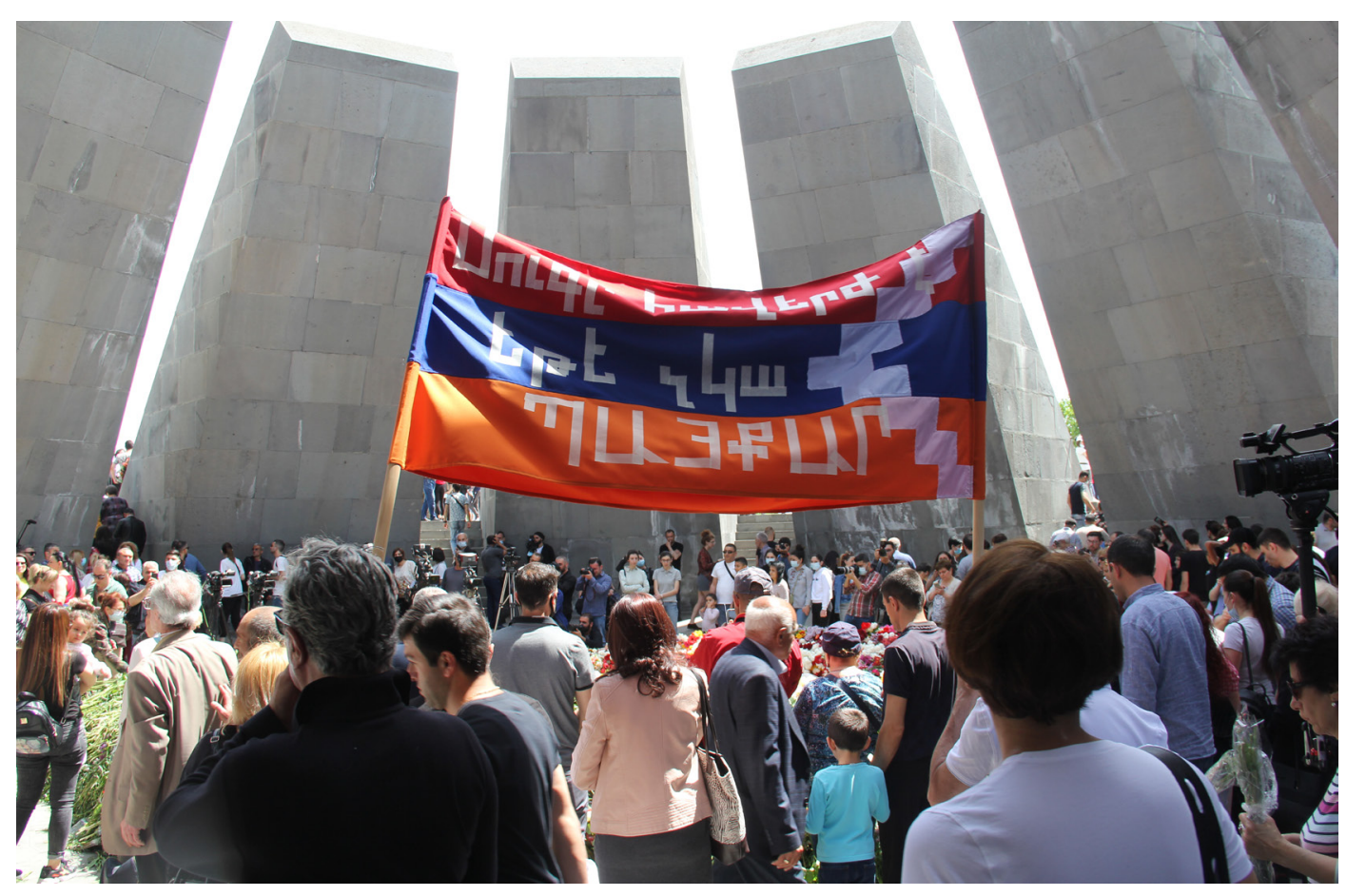

Photo VIII and IX. $106^{\text {th }}$ Anniversary of the Armenian Genocide. Author's photo, Yerevan 24.04.2021.

Photos VII and VIII show representations of remembrance in anniversary commemorations - 24 April, the symbolic date marking the beginning of the Armenian Genocide. On 24 April 1915, in Constantinople and other centres of the Ottoman Empire after the decision of the state authorities, the most important representatives of the Armenian intellectual elite were arrested. The arrests became the beginning of an organised deportations and mass slaughters against Armenian subjects of the Ottoman Empire. ${ }^{62}$ On the anniversary of this day, the most important celebrations are held to commemorate the symbolic beginning of the Armenian Genocide. The celebration usually begins the day before late in the evening with the torchlit pocession to the Genocide Memorial. On 24 April, thousands of Armenians visit Tsisternakaberd, one of the hills in the centre of Yerevan, where a monument commemorating the victims has been located since 1967 and, since the 1990s, the Armenian Genocide Museum-Institute has been operating. Armenians come to Yerevan from all over the country and from abroad, where Armenians, as a consequence of the genocide, have formed a significant and influential diaspora. Officials and embassy representatives from countries that recognise the genocide also pay visits. In their hands, they usually bring white and red flowers, symbolising innocence, and bloodshed. They are placed around an eternal fire that burns next to the spire that crowns the memorial site. Participatory observation conducted during the commemoration of the 106th anniversary of the Armenian Genocide on 24 April 2021 made it possible to observe the mechanisms of linking the narratives of memory about

62 Suny, They Can Live in the Desert, 271-272. 
the Armenian Genocide and the Nagorno-Karabakh conflict. It is worth noting that this was a significant anniversary because its most important accent became the use of the word "genocide" by US President Joe Biden, which in political practice means its recognition. As can be seen in the attached photos, banners referring to the issue of international recognition of the Artsakh Republic appeared on the monument itself, linking these issues to the memory and recognition of the genocide. At the same time, banners referring to the Karabakh issue could be seen throughout the day of the ceremony. In the context of the Second Nagorno-Karabakh War, which ended with the signing of a ceasefire agreement entering into force on 10 November 2020, the visit to the memorial by soldiers who participated in the fighting, returning from the war with severe injuries, was particularly symbolically significant. Most probably, the recognition of the genocide by one of the most important world powers, which came at a significant time immediately after the end of the Second Karabakh War, may result in an even more pronounced strengthening of the discursive connection.

\section{Discussion and Further Research}

The research question of the study is stated as follows: how the historical analogies and idea of continuity is instrumentalized as the technology of power in contemporary Armenian politics? The juxtaposition of the results of diverse research methods, allowed, in an interpretative perspective, to indicate the mechanisms and structures of the use of historical analogies and the idea of continuity in linking the phenomena of memory of the Armenian Genocide and the Nagorno-Karabakh conflict. Thus, it is not an abuse to confirm the initially stated hypothesis that being the subject to ideologization, the issue of the interrelation between the Armenian Genocide and the Nagorno-Karabakh conflict used as a technology of power in contemporary Armenian politics, is its significant variable. The discursive link is much more important, that is, the search for an answer to the question of whether this experience exists in the political consciousness in Armenia.

There are different ways of understanding the issue of historical analogy. ${ }^{63}$ In the first sense, it is a heuristic tool that helps analyse the technologies of power used in shaping hegemonic discourse. In the second sense, a historical analogy can be a justification or explanation in discursive space. In the third sense, the historical analogy functions as a reason for making specific decisions. In the fourth understanding, essentialist historical analogy occurs as the perception of a situation as analogous to prior experience. For this reason, it is

63 Robert Axelrod and Larissa Forster, "How Historical Analogies in Newspapers of Five Countries Make Sense of Major Events: 9/11, Mumbai and Tahrir Square," Research in Economics 71, no. 1 (2017): 8-19; Paul Bartha, "Analogy and Analogical Reasoning," in The Stanford Encyclopedia of Philosophy, ed. Edward N. Zalta (2019); Peter J. Dortmans and Eleanor Eiffe, "An Examination of Future Scenarios Using Historical Analogy," Futures 36, no. 10 (2004): 1049-1462; James Ferguson, "Proletarian Politics Today: On the Perils and Possibilities of Historical Analogy," Comparative Studies in Society and History 61, no. 1 (2019): 4-22; Hall Gardner, IR Theory, Historical Analogy, and Major Power War (London: Palgrave Macmillan, 2019); Djouaria Ghilani et al., "Looking Forward to the Past: An Interdisciplinary Discussion on the Use of Historical Analogies and Their Effects," Memory Studies 10, no. 3 (2017): 274-285; Yahya Kamali and Sedighe Sheikhzadeh Jooshani, "Reasoning in Foreign Policy Making from the Analogy Perspective: The Case Study of Iran's Nuclear Issue," Asian Politics \& Policy 11, no. 2 (2019): 208-226; Andrew Mumford, "Parallels, Prescience and the Past: Analogical Reasoning and Contemporary International Politics," International Politics 52, no. 1 (2015): 1-19. 
difficult to have one precise definition, but referring to the wide spectrum of those proposed by researchers, it is possible to construct the following formulation: "a historical analogy is a present meaningful reference to a past situation and experience, in the context of a current discourse." Ideological continuity is understood similarly, as a kind of historical analogy. Thus, it operates similarly to social memory, which, while focusing on the content of the past, functions dominantly in the present. At the same time, historical analogy and continuity are technologies of power that also requires explanation.

The origin of the term is Michel Foucault's reflections on "governmentality," undertaken mainly during his lectures at the College de France. ${ }^{64}$ The use of this category allows for a broader analytical view of the problem under study. Narratives in discourse are thus a form of social practice, discursive formations must pass an "institutional test" to become part of it. Thus, what is significant goes beyond the causal understanding of political action (from sender to receiver). What means politically must be socially structured. Consistently, then, "technologies of power" are not simple "political tools" that serve to establish dominance and sustain power. As Monika Bobako writes: “(...)[the technology of power is] productive and regulative, realized through a whole complex of practices, discourses, institutions, knowledge systems that make up complex tactics for managing populations and producing subjectivity." 65 Nikolas Rose shortly defines technologies of power (government) as "(...) those technologies imbued with aspirations for the shaping of conduct in the hope of producing certain desired effects and averting certain undesired events. " 66

\section{Explanation of results}

The exploratory case study has proven that historical analogy understood as a technology of power stands as a useful heuristic tool of analysis. There is no doubt, based on the expert interviews, the online questionnaire, and the interpretation of the representation in the public space, that historical analogy occurs as the perception of a situation as analogous to prior experience. How historical analogy and ideological continuity are present in the discursive practice of contemporary Armenia indicates that two other understandings of this category are present explicitly, intertwining with each other in narratives about the past and present. Historical analogy is used as a justification or explanation in discursive space. This is especially true of how the narrative of the Azerbaijani-Armenian rivalry is constructed, constructed on the analogy of Turkish-Armenian relations over 100 years ago. "Offensive defence" against the invasion of the "Other" Turk is thus a drawing, based on historical analogy, of an omission in the past that resulted in genocide.

64 Michel Foucault, Society Must Be Defended. Lectures at the Collège de France, 1975-1976, trans. David Macey, vol. V, Lectures at the Collège de France, 1975-1976 (London: Picador, 2003); Michel Foucault, Security, Territory, Population: Lectures at the Collège de France 1977--1978, trans. Graham Burchell, (New York: Picador, 2009); Michel Foucault, The Birth of Biopolitics: Lectures at the Collège de France, 1978--1979 (New York: Picador, 2010).

65 Monika Bobako, Islamofobia Jako Technologia Władzy. Studium z Antropologii Politycznej (Kraków: UNIVERSITAS, 2017), 47.

66 Nikolas Rose, Powers of Freedom: Reframing Political Thought (Cambridge: Cambridge University Press, 1999), 52. 
The issue of defence is closely linked to the issue of explaining the sacrifice that Armenians must make in the face of an external threat. As public representations indicate, in the case of the Nagorno-Karabakh conflict it is analogous to how sacrifice was understood during the defence of Eastern Armenia during the Caucasus offensive of the Army of Islam, or during the Great Patriotic War. This way of thinking is coupled with a specific attitude of victory through sacrifice, which, originating in the commemoration of the Great Patriotic War, influenced the perception of Armenian success in the First Karabakh War. In this case, the historical analogy is combined with its subsequent understanding, that is, functioning as a reason for specific decisions. The limitation of sovereignty, both in the dimension of international alliances (Russia) and civil subjectivity (especially during the rule of the Republican Party of Armenia), is conditioned by the necessary, explained by references to the past.

Consequently, another figure of analogy emerges - the idea of survival. The fact that a genocide has been survived makes the survival of the nation justify and explain political reality, but it also causes concrete decisions to be made. This is particularly important as the research indicates that these are not only reactive decisions but also proactive ones. The difference comes down to the fact that the use of survival issues in politics is explored. The traumatisation of society and the experience of genocide itself becomes a useful technology of power.

An assumption that can be drawn from the results of the research is the issue of distinguishing the discursive exploration of the connection with the absence of an actual official policy pursued by the Armenian state in the international arena. In this context, it is also significant to distinguish between a narrative created for internal use, in which the combination of two narratives must certainly be considered a technology of power, and a narrative constructed for external use, i.e., used in diplomacy and external relations. In the latter case, if references are made at all they are cautious, leaving aside categorical statements. It is thus a significant connection in political terms.

The conclusion that can be drawn from the analysis of the material obtained from the preliminary research is that the narratives about the undoubtedly occurring interrelation between the two phenomena stem from Armenian perceptions about the shape of discourse in Turkey and Azerbaijan. However, as Vicken Cheterian's research indicates, the portrayal of this interrelation in both Turkish and Azerbaijani discourse is much more nuanced than it is presented in narratives in Armenia. ${ }^{67}$ Without in-depth historical research, as well as cross-sectional sociological studies in Turkey and Azerbaijan, there is no way to confirm the existence of a real "genocide" policy and continuity so deeply rooted in Armenian discourse. Nevertheless, even if the existence of an actual "genocide policy" pursued by the adversaries of the modern Armenian state is questionable, there is no doubt that the notion of its facticity is an extremely significant technology of power and, consequently, a driving force in contemporary politics in Armenia.

67 Cheterian, "The Uses and Abuses of History"; Ceylan Tokluoglu, "The Political Discourse of the Azerbaijani Elite on the Nagorno-Karabakh Conflict (1991-2009)," Europe-Asia Studies 63, no. 7 (2011): 1223-1252. 


\section{Unexpected findings}

The transformation and political change in Armenia were analysed both as separate case studies and from a comparative perspective. ${ }^{68}$ These perspectives - historical, political, and sociological - need to be complemented by an analysis of the impact on political change and transformation of the combined discursive phenomena of the memory of the Armenian Genocide and the Nagorno-Karabakh conflict. Thus, the primary question of the extended research of which this preliminary case study is a part is: how the instrumentalized discursive interrelation between narratives of memory of the Armenian Genocide and the Nagorno-Karabakh conflict impact the political change in Armenia between 1991 and 2020? The broad hypothesis set for the in-depth study stated as follows: politics of memory has a decisive impact on the transformation and political change in Post-Soviet Armenia. One element of this influence hypothesised is the use of historical analogy and the idea of continuity of historical experience as a technology of power. In this context, the study tested the potential change in this issue because of the Armenian Velvet Revolution of 2018 and the Second Karabakh War of 2020. The findings indicate that the impact of instrumentalising the connection between the phenomena on political change, in this case, was not necessarily significant. However, this exploratory case study indicated that within this politics of memory, one of the most significant causal elements for political change is the correlation of the narrative of the Armenian Genocide and the issue of the Nagorno-Karabakh conflict. Despite the existence of diversified perspectives on the interrelation between the Armenian Genocide and Nagorno-Karabakh conflict (including the attempts of decisive separation), the instrumentalization and ideologization of narratives of memory profoundly dominate the mainstream pattern of past representation. Consequently, it can have a definitive impact on the dynamics of political change. Thus, for further research, it is required to analyse the impact of instrumentalized connection on the most significant political changes in contemporary Armenian politics within the timeframe between 1991-2019.

\section{Limitations and Weaknesses}

It is necessary to draw attention to limitations and restrictions. The primary one is the qualitative nature of the survey itself, which results in the fact that they cannot be seen as representative surveys. As qualitative research, the results presented should be considered as

\footnotetext{
68 Sven Eliaeson, Lyudmila Harutyunyan, and Larissa Titarenko, After the Soviet Empire: Legacies and Pathways (Leiden; Boston: Brill, 2015); Nora Dudwick, "Political Transformations in Postcommunist Armenia: Images and Realities," in Conflict, Cleavage, and Change in Central Asia and the Caucasus, ed. Karen Dawisha and Bruce Parrott (Cambridge: Cambridge University Press, 1997); Nora C Dudwick, "Memory, Identity and Politics in Armenia," (PhD, 1994), 1-476; Transcaucasia, Nationalism, and Social Change: Essays in the History of Armenia, Azerbaijan, and Georgia, ed. Ronald Suny (Ann Arbor: University of Michigan Press, 1996); Donnacha Ó Ó Beacháin and Abel Polese, The Colour Revolutions in the Former Soviet Republics: Successes and Failures (London and New York: Routledge, 2010); Alexander Agadjanian, Ansgar Jödicke, and Evert van der Zweerde, Religion, Nation and Democracy in the South Caucasus (London and New York: Routledge, 2014); Taras Kuzio, “Transition in Post-Communist States: Triple or Quadruple?” Politics 21, no. 3 (2001): 16877; Hale, Patronal Politics; Evgeny Finkel and Yitzhak M. Brudny, "No More Colour! Authoritarian Regimes and Colour Revolutions in Eurasia," Democratization 19, no. 1 (2012): 1-14.
} 
a kind of descriptive for existing phenomena with an indication that there are many cracks and crevices in the discourse where the past is interpreted and represented differently. Another significant limitation follows from this. When analysing two historical and political events, the leading question for the historian should be whether the combination and correlation of the two phenomena under study is justified in past events. This question is not the most important one in this research, because "truthfulness" and "validity" are secondary if, in the discourse, the discursive formation occurs. If at an imagined social and political level the validity of the connection can be confirmed, and this has been demonstrated by the research, then "historicity" is of secondary importance. In other words, the influence of this relationship is important for political change in Armenia after 1991, regardless of whether its actual occurrence can be proven within the framework of a classically understood history. Nevertheless, during further in-depth research, the historical perspective is necessary.

The research has undoubtedly shown how instrumental the technology of power in contemporary Armenian politics is in instrumentalizing the question of historical analogy and the idea of continuity. Preliminary research also confirms the suitability of the theoretical framework adopted, with the clear indication that it does not exhaust the entire potential space of the object of analysis. More broadly, the research suggests the need for a wider exploration of the content, structures, and forms of narratives, which are not only political tools but also social discursive practice.

\section{Conclusion}

The conclusion that can be drawn with certainty is that, as technologies of power, the instrumentalization of the connection between the two phenomena is of more than average importance in Armenia. Thus, the presented research fulfils the role of added value to the aforementioned case studies on memory and collective identity in contemporary Armenia, addressing this issue from the rare perspective of investigation over interrelation between the Armenian Genocide and the Nagorno-Karabakh conflict. Because of this, the presumption of broader research about the possible significant impact of this connection on the issue of political change in Armenia cannot be dismissed. Moreover, the preliminary research suggests the potential for investigating the historical correlation. Through broader archival research in Armenia, the possibility of juxtaposing discursive technologies of power with historical analysis emerges. It makes the research appropriate to be continued. Too little time has yet passed to indicate what impact the defeat in the Second Nagorno-Karabakh War will have on the account of the memory of the Armenian Genocide and the narrative of Nagorno-Karabakh. Nevertheless, the search for an in-depth answer as to how significant a variable defeat will be for the shape of the discourse represents an important space for future research. What matters here is not only the context of impact on political change in general but the dynamics of transforming the identity of victory through sacrifice (characteristic of the First Karabakh War), into a new form. It is an open question to what extent it will be discursively intertwined with the idea of remembering the Armenian Genocide. 


\section{Acknowledgments}

I would like, with all sincerity of heart, to thank the Armenian Genocide Museum-Institute for the Lemkin scholarship that made it possible to conduct research in Armenia and to present its results in the form of an article. Thank you for your openness, support and inspiration at an extremely difficult time marked by the consequences of the Second Nagorno-Karabakh War, preparations for early parliamentary elections and the Covid-19 pandemic. 


\section{Appendices}

Tables with captions

Table I. In your opinion, is there a connection between the Nagorno-Karabakh conflict and the Armenian Genocide issue?

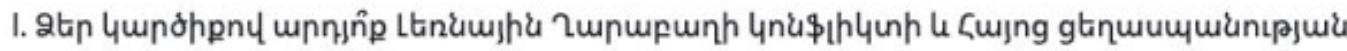
pưnph ưpqu पumu् पw:

36 odpowiedzi

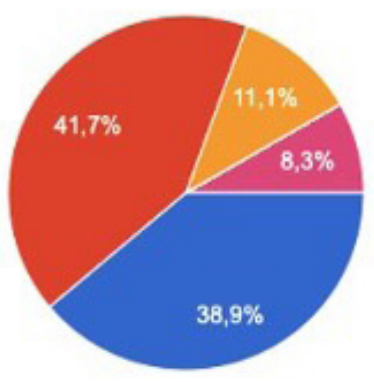

1) Uhuirzuliuly wjn

2) u,n

3) U4tbin 2nun wjn

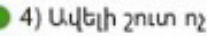

5) $n_{2}$

6) Uhurazuiauly nz

7) 7dulun $t$ wut!

8) 2qhuntú

Table II. If yes, how significant do you think the connection between the Armenian Genocide and the Nagorno-Karabakh conflict is?

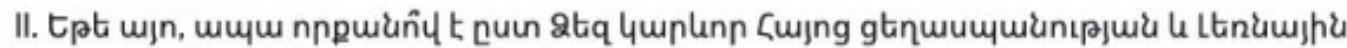

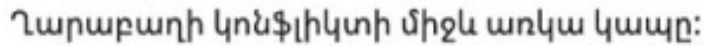

35 odpowiedzi

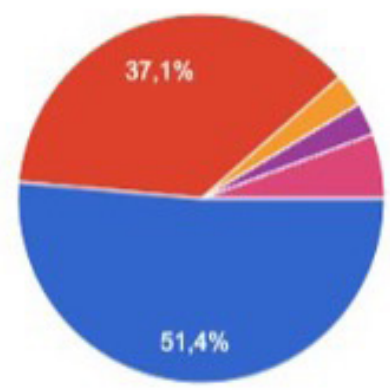

1) Uhwirzutawl Gunlenn t:

2) 4wnlann 5

3) Uytgh 2 nun luplunn $t$

4) Uybah 2nun wilqunlenn $t$

5) 4 wnlunn 25

6) Upuizzusuly 4mplenn 25

7) 7dump t wut!

8) Rqhuntú 
Table III. In your opinion, does the potential recognition of the Armenian Genocide by Turkey depend on the resolution of the Nagorno-Karabakh conflict?

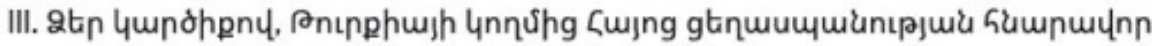

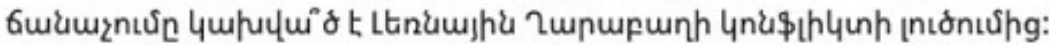

36 odpowiedzi

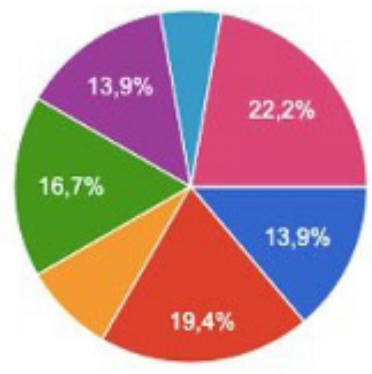
1) Uhừzutuml wj̣n
2) Uyn
3) Uutth 2niun wjn
4) Uyttin 2nun ny
5) $n_{2}$
6) Unuirzuliuly nz
7) 7dump t wut!
8) 2qhuntus

Table IV. In your opinion, is the potential resolution of the Nagorno-Karabakh conflict dependent on Turkey's recognition of the Armenian Genocide?

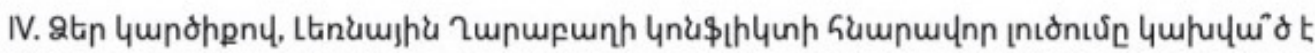

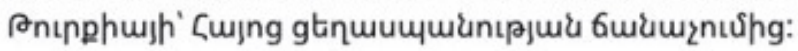

36 odpowiedzi

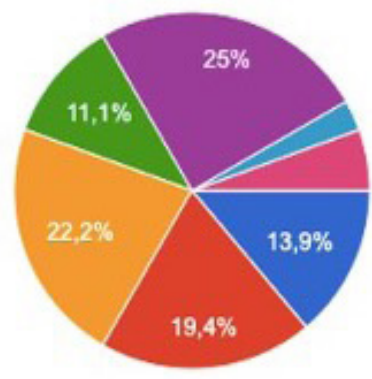

1) Uhurtazutiuly ujn

2) u!n

3) Uytth 2nun wjn

4) Uytogh 2num nz

5) $n_{2}$

6) Uhuitzzutuly nz

7) 7dulun t wut!

8) 2qhuntú 
Table V. In your opinion, does Armenia have a policy that emphasizes the connection between the commemoration of the Armenian Genocide and the Nagorno-Karabakh conflict?

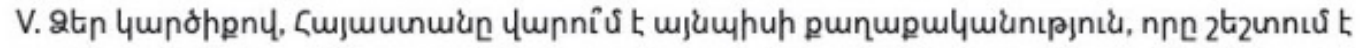

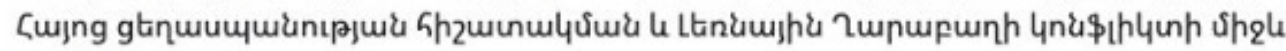
unlym पшuщn:

36 odpowiedzi

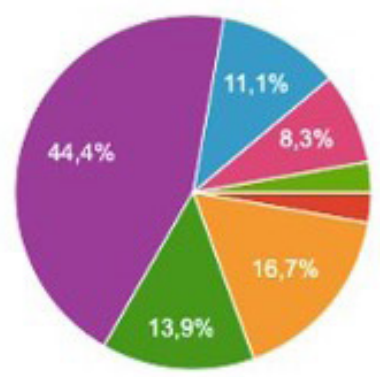

1) Uhwizmiauly wjn

2) u,n

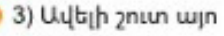

4) Uultin 2num nz

5) $n_{2}$

6) Uhuirzuiauly nz

7) 7dump twut!

8) 2qhuntus

Table VI. If yes, do you think that linking the Armenian Genocide to the Nagorno-Karabakh conflict is the right policy direction for Armenia?

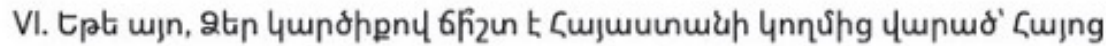

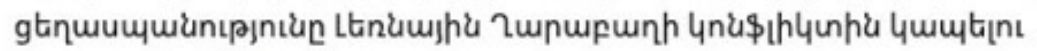
punupulquantspntun:

32 odpowiedzi

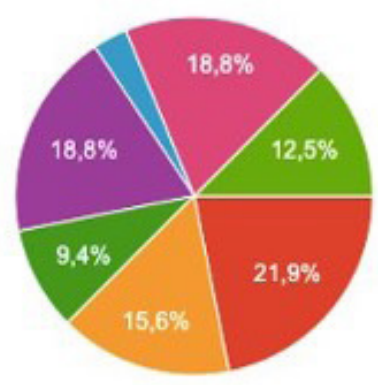

1) Uhuilizuiawly wjn

2) u,n

3) U.tth 2ntun wjn

4) uytth 2ntun $n_{2}$

5) $n_{2}$

6) Uhuirzuiauly nz

7) 7dum t wut!

8) 2qhuntos 
Table VII. In your opinion, has Armenian policy towards the relationship of recognition and commemoration of the Armenian Genocide and the Nagorno-Karabakh conflict changed after the change of power in 2018 ?

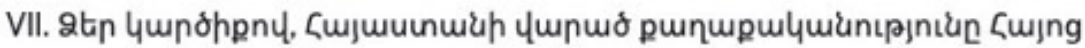

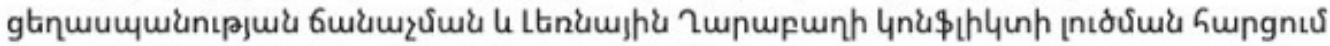

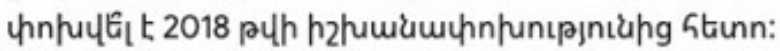

36 odpowiedzi

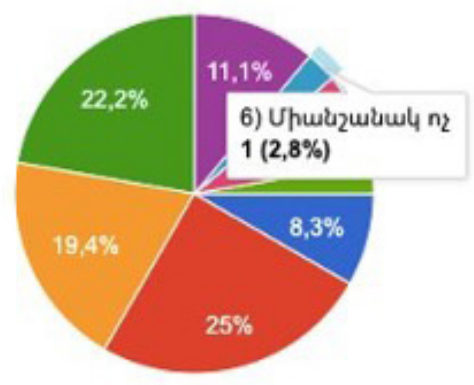

1) Uhuirquiauly min

2) Ujn

3) Uytth $2^{\text {nun ujn }}$

4) Uytuh znun nz

5) $\mathrm{n}_{2}$

6) Uhuirazu'auly n?

7) 7dum t wut!

8) 2qhuntú

Table VIII. If yes, how would you rate the extent to which the use of narratives about the relationship between these issues has intensified after 2018 ?

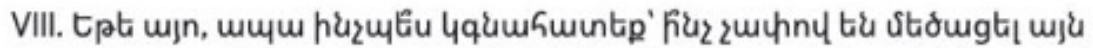

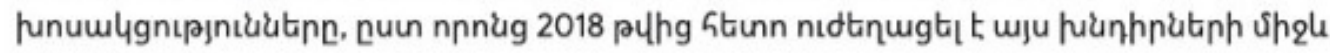
tпưd पшu्पn:

33 odpowiedzi

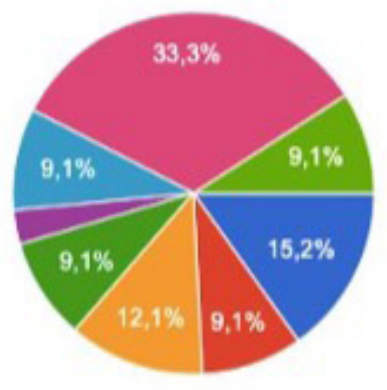

1) Uhuirizutiuly w6tat

2) $u 6 b_{i} t$

3) Uutbin 2nin w6tit

4) Uytgh 2nun tuluqtit

5) uluqut $t$

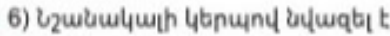

7) ?dulun t wub!

8) 2qhuntus 
Table IX. In your opinion, should the issue of resolving the Nagorno-Karabakh conflict be combined with the issue of the Armenian Genocide?

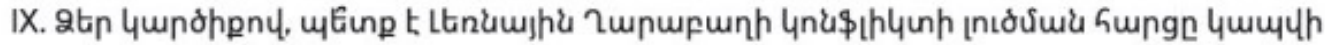

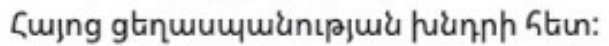

36 odpowiedzi

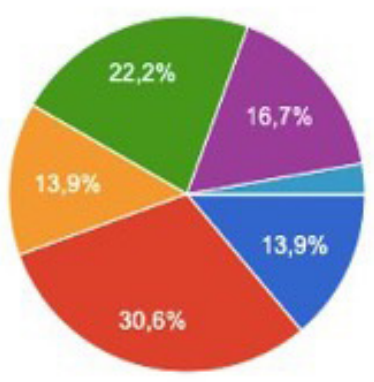

1) Uhuirizuiml wan

2) $u_{j n}$

3) Uytth 2ntun ujn

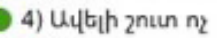

5) $n_{2}$

6) Upuirzutauly nz

7) 7dulun t wuta

8) 2qhuntus 